\title{
Combining Industrial Organization and Econometric Methods in Price Transmission Analysis
}

\author{
Dissertation \\ to obtain the Ph.D. degree in the \\ International Ph.D. Program for Agricultural Sciences in Göttingen (IPAG) \\ at the faculty of Agricultural Sciences, \\ Georg-August-University Göttingen, Germany \\ presented by \\ Alejandro Acosta \\ born in Colombia
}

Göttingen, December 2016 
D7

1. Name of supervisor: Prof. Dr. Stephan von Cramon-Taubadel

2. Name of co-supervisors: Prof. Dr. Rico Ihle \& Dr. Alberto Valdés 


\section{Acknowledgements}

I wish to express my sincere appreciation to my Ph.D. supervisors, Professor Dr. Stephan von Cramon-Taubadel, Professor Dr. Rico Ihle, and Dr. Alberto Valdés. I feel honoured to have you as my Ph.D. committee.

My sincere gratitude to my main supervisor, Professor Dr. Stephan von Cramon-Taubadel for his continuous support and guidance during my $\mathrm{Ph} . \mathrm{D}$. study. Your vast knowledge and experience combined with leadership and motivation created the perfect environment to explore my research ideas. The way how you guide, with thoughtful, critical, and constructive comments is inspiring.

I would like to thank Professor Dr. Rico Ihle and Dr. Alberto Valdés. Rico, I benefitted tremendously from having an advisor with your level of econometric expertise to discuss methodological questions. I appreciate your willingness and availability to review several drafts of my manuscripts. Alberto, thank you for being my mentor for the past ten years. Your deep understanding of economics has been fundamental to widen my research approach.

I would like to extend my appreciation to the editors, anonymous reviewers, and colleagues, for their effort to review my manuscripts; your comments and suggestions were important to strengthen my research. I would like also to take this opportunity to thank the Faculty's Academic Advisory Service, for precious collaboration.

Last but not the least, I would like to thank my family and friends, some of them no longer around, for supporting me throughout this journey. Thank you for your unconditional support. 


\section{Summary}

The degree of competition and level of price transmission in food markets have important effects on the welfare level of consumers and producers. Thus, substantial attention has been paid to the analysis of price transmission in food markets. Traditionally, price transmission analyses have focused on applying econometric methods to assess whether prices are cointegrated, the order of cointegration and the adjustment speed. In contrast, less attention has been devoted to the theoretical underpinnings, the structure of the market and the interpretation of results. To address this gap, this study explores how to combine industrial organization methods and time-series econometrics in price transmission analyses to inform policy choices. With this aim, this research uses a three-step approach. First, I employ industrial organization methods to analyse the structure of the milk market. Second, I use time-series econometrics to assess the price dynamics. Finally, I triangulate the different sources of information, bringing together the evidence derived from both analyses. The study illustrates the complementarity of these methods to gain a better understanding of the findings, to corroborate theoretical propositions and to advance theoretical concepts. The study uses the milk market in Panama to illustrate this approach. 


\title{
Contents
}

\author{
Sumary \\ List of Figures \\ List of Tables
}

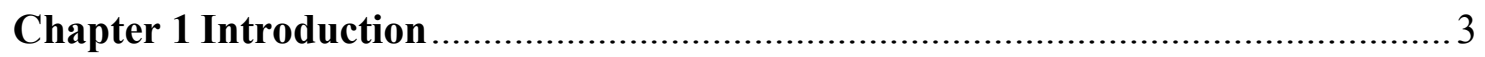

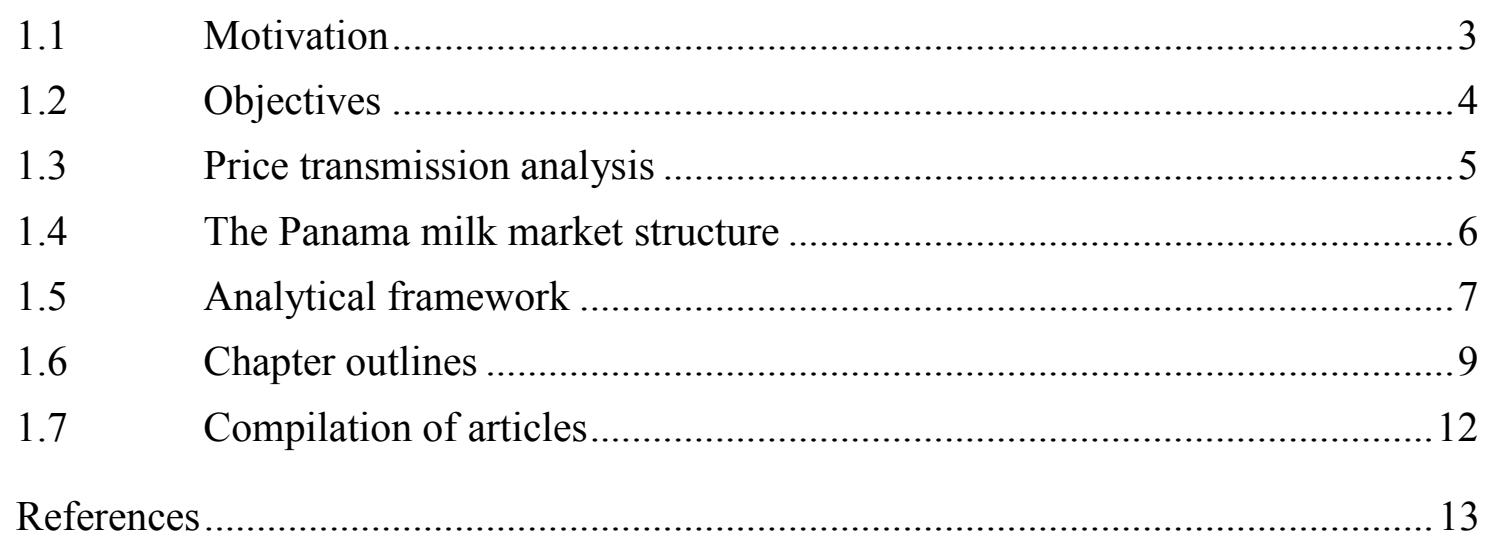

\section{Chapter 2 Spatial Price Transmission of Soaring Milk Prices from Global to}

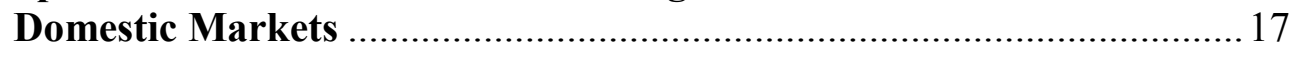

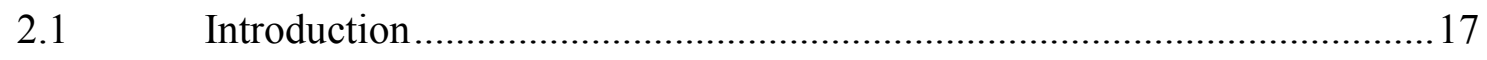

2.2 Characteristics of the dairy trade market in Panama .................................. 19

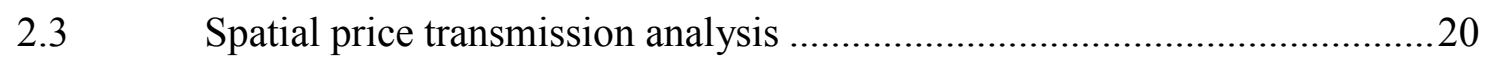

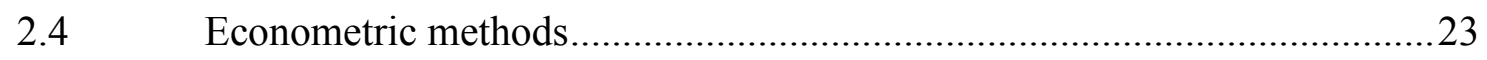

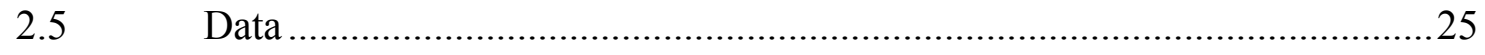

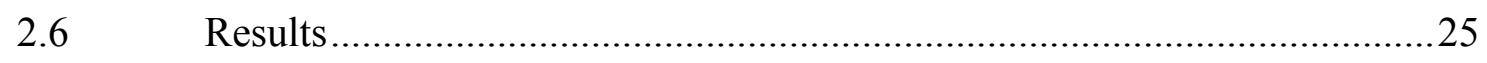

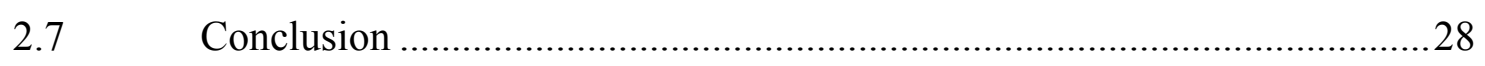

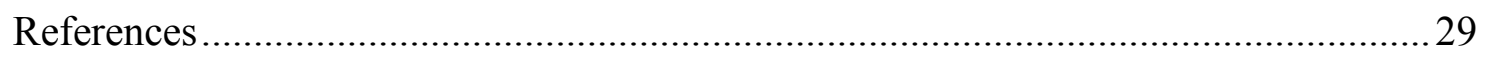


Chapter 3 Vertical Price Transmission of Milk Prices: Are Small Dairy Producers Efficiently Integrated into Markets?

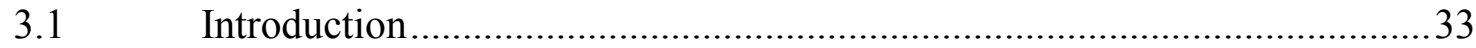

Structure of the milk market in Panama …....................................................... 35

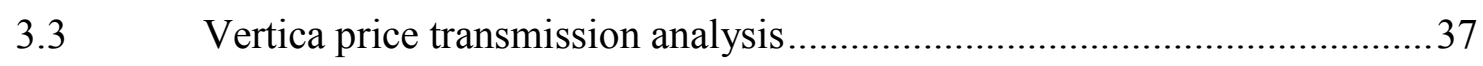

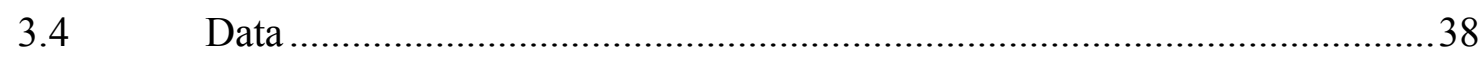

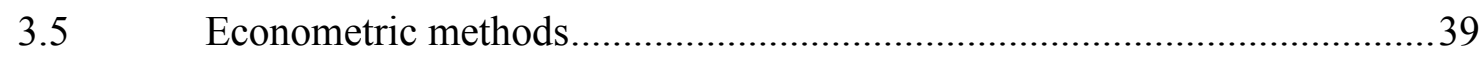

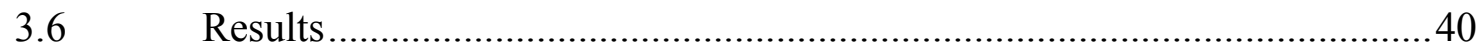

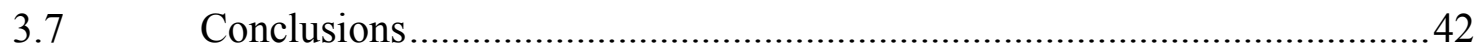

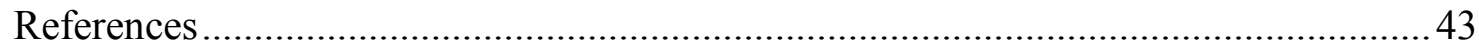

Chapter 4 Combining Industrial Organization and Econometric Methods in Price

Transmission Analysis ................................................................... 45

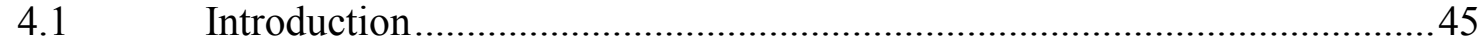

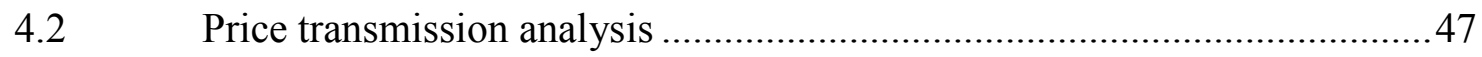

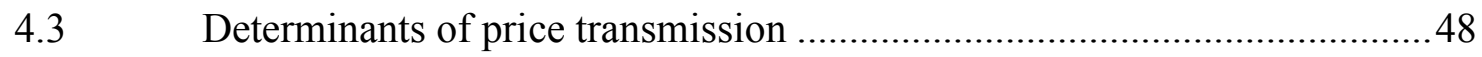

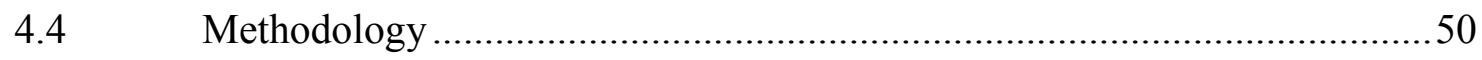

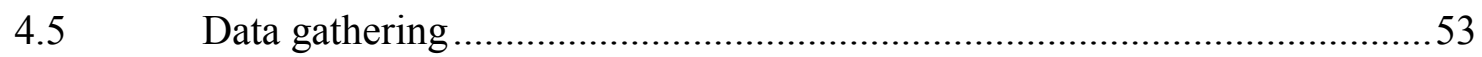

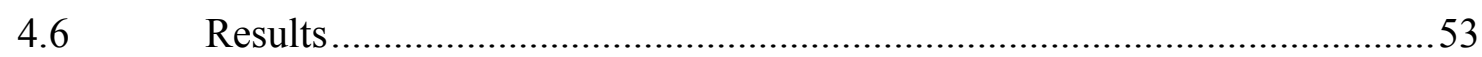

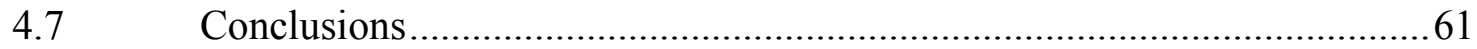

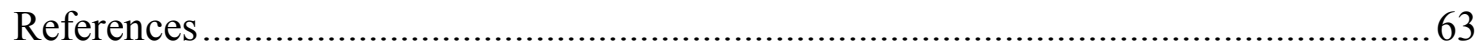

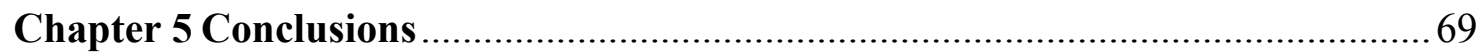

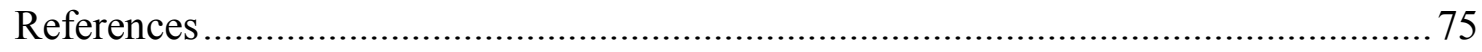




\section{List of Figures}

Figure 1.1 Panama's milk market structure ...................................................................... 7

Figure 1.2 Analytical framework Source: Author ......................................................... 8

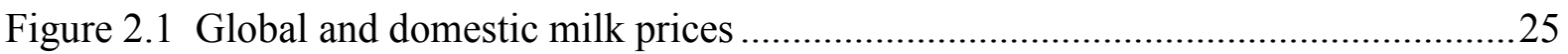

Figure 3.1- Milk price trends at producer and wholesaler levels...........................................34

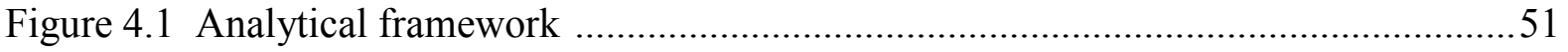

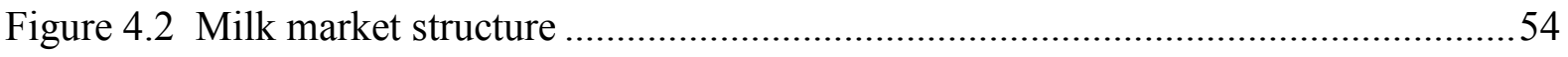

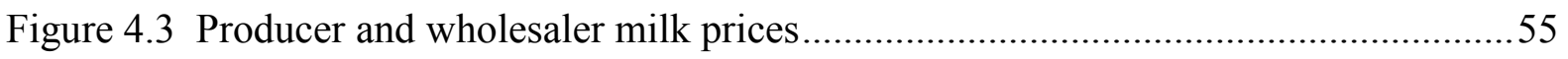





\section{List of Tables}

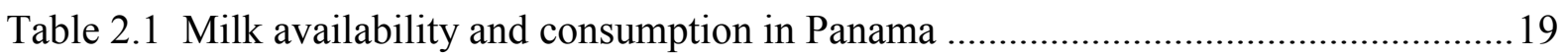

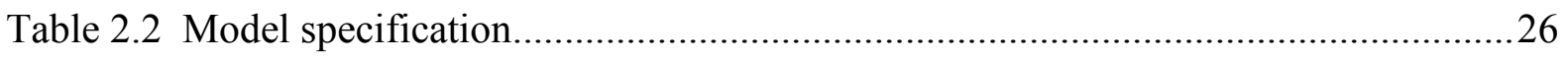

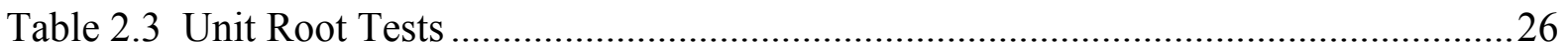

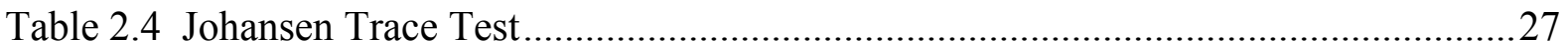

Table 3.1 Cattle inventory breakdown in Panama ............................................................. 35

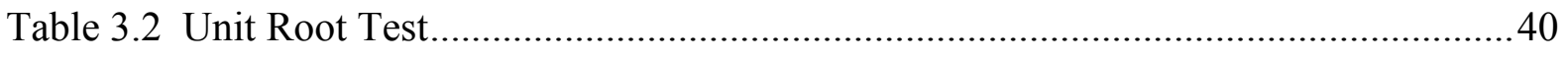

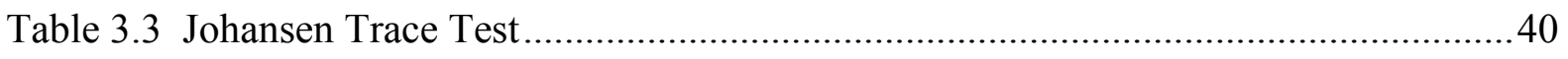

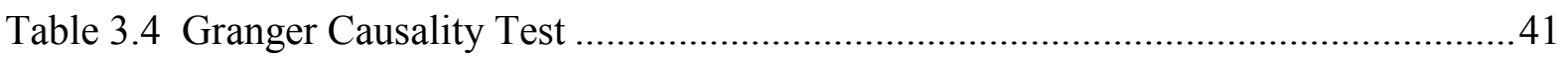

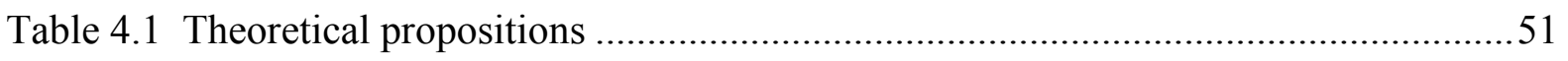

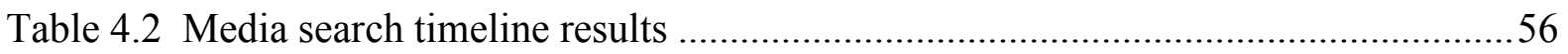

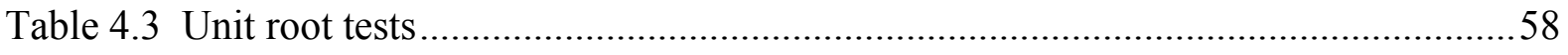

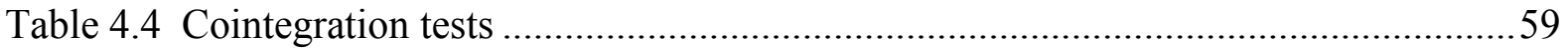

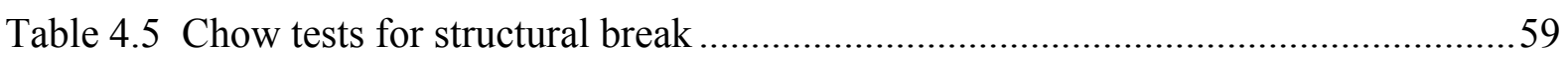

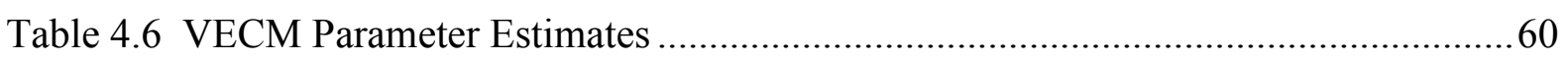

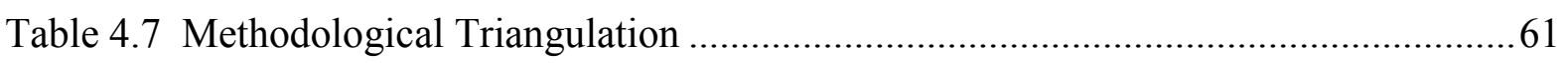





\section{Chapter 1 Introduction}

\subsection{Motivation}

The degree of competition and the level of price transmission in food markets have important effects on the welfare level of consumers and producers (Sexton and Lavoie, 2001). Recent studies (Dawe et al., 2015; Dawe and Maltsoglou, 2014) stress the importance of deeply understanding the price dynamics of food markets in explaining the welfare effects of food policy measures. Current trends in mergers and acquisitions, coupled with increases in industry concentration have captured the attention of policymakers regarding the performance of food markets and the lack of transparency in the transmission of prices (McCorriston, 2013).

In Panama, articles appeared in various newspapers in 2007 suggesting that processors agreed among themselves on the price of milk paid to producers, which highlighted the lack of transparency in the milk market, motivated the national antitrust authority to open an investigation against industrial processors over the alleged use of monopolistic practices. The investigation found that four major processors exchanged information that ultimately led them to agree on the purchase price of milk paid to producers. Dairy producers expressed their concerns about the competitiveness of the dairy supply chain, arguing that price changes are not being transmitted efficiently from global to domestic markets and between wholesalers and producers. In this context, this study assesses the efficiency level of Panama's dairy market by examining the degree of spatial and vertical transmission of milk prices between global and domestic markets, as well as between wholesalers and small dairy producers.

Substantial attention has been given to analysis of the level of price transmission in food markets during recent decades (for reviews see Meyer and von Cramon-Taubadel, 2004; Frey and Manera, 2007; Bakucs et al, 2014., Lloyd). Traditionally, price transmission 
analysis has focused on applying econometric methods to assess if prices are co-integrated, the order of cointegration and the adjustment speed. However, less attention has been devoted to the theoretical underpinnings, the understanding of the market structure, and the interpretation of results (Meyer and von Cramon-Taubadel, 2004). Goodwin and Vavra (2009), in an overview of the empirical literature addressing vertical and spatial price transmission, highlight that the results of price transmission analysis are not sufficiently informative without a deeper understanding of the market structure relevant to the commodity in question. Moreover, Miller and Hayenga (2001) note that although economists have proposed many approaches for price transmission analyses, the econometric methods often used are limited because they cannot identify plausible explanations of price behaviour under competing theories.

Acknowledgement of these issues has stimulated recent studies (Lloyd et al. 2004; Brümmer et al., 2009; Ihle et al., 2012; Götz et al., 2013) to incorporate the use of market structure information in price transmission analyses. This study takes this approach further by exploring how to combine industrial organization (IO) and econometric research methods for price transmission analysis to inform policy choices. With this aim, this research uses a three-step approach. First, we employ IO methods to analyse the structure of the milk market. Second, we use time-series econometrics to analyse the price dynamics. Finally, we triangulate the different sources of information to gain a better understanding of the interrelations among the factors that influence the transmission of prices, linking the evidence with theory.

\subsection{Objectives}

- Gain a deeper understanding of how the structure of markets and behaviour of agents affect the level of price transmission in food markets.

- Explore how to combine industrial organization and time-series econometrics methods in price transmission.

- Assess the extent and determinants of spatial and vertical price transmission in Panama's dairy market. 


\subsection{Price transmission analysis}

Price transmission analyses use different modifications of a model introduced by Granger (1981) and then extended by Engel and Granger (1987) based on cointegration theory. Cointegration theory stipulates that if the linear combination of nonstationary series is stationary, then the series are said to be cointegrated (Engel and Granger, 1987). A major aspect of cointegrated series is that their dynamics are affected by the degree of deviations from the long-run equilibrium relationship (Enders, 1998). This implies that a close relationship exists between cointegration and ECM, as suggested by Granger (1981). ECMs have been widely used in price transmission under the idea that a fraction of a disadjustment from one period is corrected in the next period (Engel and Granger, 1987). Studies have found that the transmission of food prices tends to be nonlinear, rather than linear (Hassouneh et al., 2012); indeed, the nonlinear transmission of prices seems to be the rule rather than the exception (Meyer and von Cramon-Taubadel, 2004). In this regard, much of the research on price transmission has focused on capturing these nonlinearities (Kinnucan et al., 1987; Serra and Goodwin, 2002; Awokuse and Wang, 2009: Bolotova et al., 2012; McLaren, 2015).

Following the concept of the non-symmetric ECM introduced by Granger and Lee (1989), von Cramon-Taubadel (1998) propose splitting the error correction term into positive and negative components to test for asymmetries in the transmission of prices, depending on whether they increase or decrease. As indicated by Abdulai (2000), under the presence of transaction costs, movement towards equilibrium does not always occur. Awokuse and Wang (2009) highlight that studies that ignore threshold effects in the transmission of prices may be misleading. To overcome this problem, studies have applied different modifications of threshold vector error correction models (TVECM)s as a way to incorporate the effects of transaction costs in price transmission analyses, allowing error correction specifications to adequately capture nonlinear and threshold-type price adjustments (Goodwin and Holt, 1999; Serra and Goodwin, 2002; Balcome et al., 2007 Bekkerman et al., 2013).

In recent years, regime-dependent vector error correction models (RVECMs) have received notable attention in the literature. According to Ihle et al. (2011) the parameters governing price interdependence might not be constant, indicating that if this characteristic is disregarded the model will be misspecified. Hassouneh et al. (2010) use a regime-switching 
vector error correction model (RVECM) to assess the impact of bovine spongiform encephalopathy (BSE) outbreaks in the Spanish dairy sector and show that the BSE crises affected producer and retailer prices differently. Busse et al. (2012) employ a Markovswitching vector error correction model (MS-VECM) to analyse changes in the relationship between diesel and biodiesel prices due to changes in market conditions. Amikuzuno and von Cramon-Taubadel (2012) apply a modification of the VECM with seasonally regimedependent adjustment parameters, showing that not accounting for seasonality can lead to compound estimates of the parameters that indicate price transmission behaviour but overlook seasonal differences in the price dynamics.

\subsection{The Panama milk market structure}

Each year, Panama produce around 206 million kg of fluid milk equivalent (FME), import 112 million $\mathrm{kg}$ of FME, and export 22 million $\mathrm{kg}$ of FME. Thus, total availability of milk is about 296 million $\mathrm{kg}$ of FME. The dependency ratio is 38 per cent and the average consumption per capita is 77 litres per year.

Figure 1.1 Panama's milk market structure

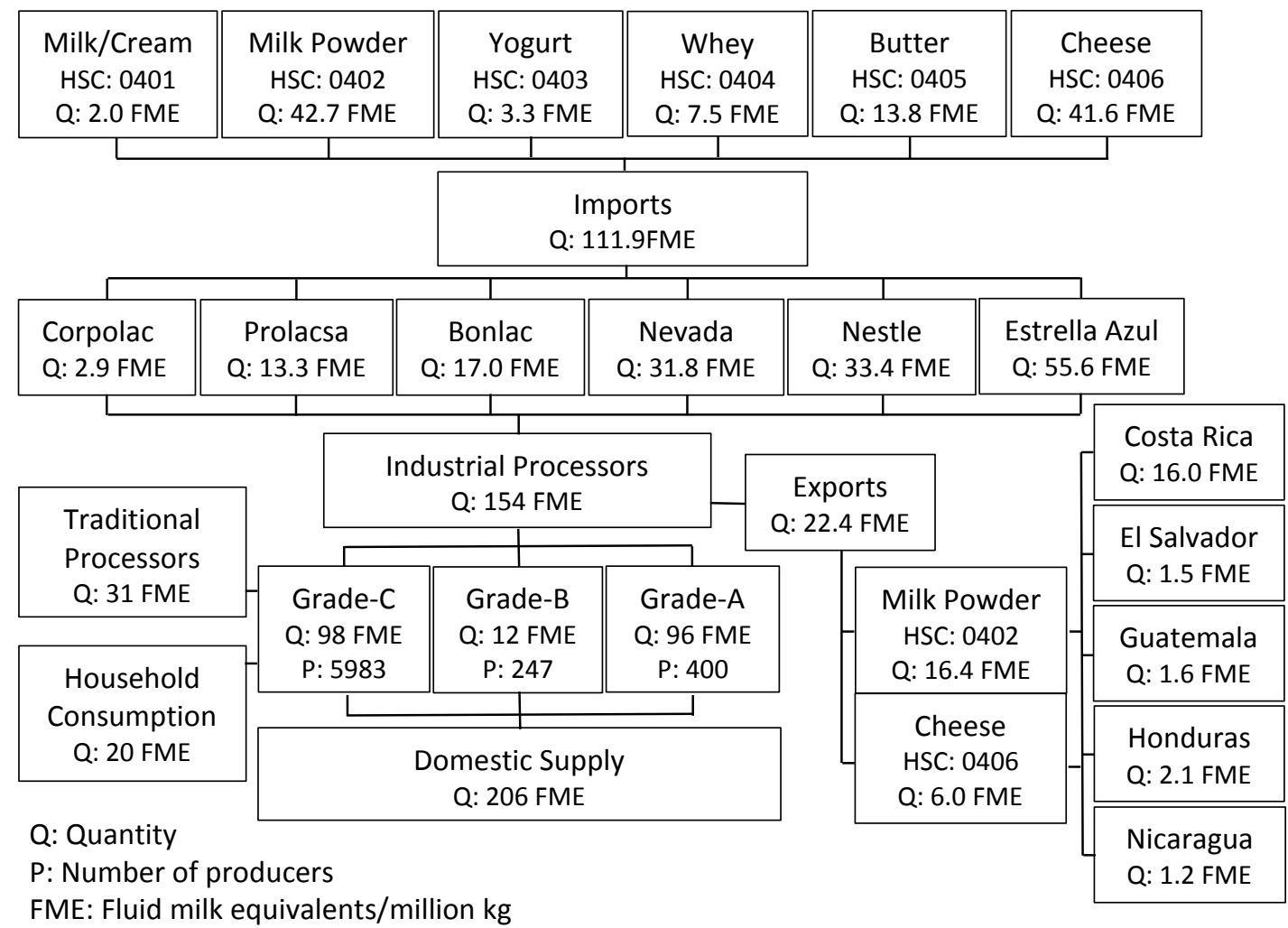


As shown in Figure 1.1, there are about 6630 milk producers, with 6 per cent producing Grade A milk, 4 per cent producing Grade B milk, and 90 per cent producing Grade $\mathrm{C}$ milk. From the 206 million kg the country produced in 2013, 46 per cent was Grade A, 6 per cent was Grade B and 48 per cent was Grade C. Grades A and B are used to supply the domestic market with fresh milk, while Grade $\mathrm{C}$ is used mainly for industrial purposes, the elaboration of traditional cheese and self-consumption at the farm level. From the entire domestic supply, 75 per cent goes to the industry, 15 per cent to traditional processors and the remaining 10 per cent is for household consumption.

There are six major milk processing companies in the country. In 2013, the three biggest of these processors absorbed nearly 80 per cent of the supply oriented to the industrial market. During the last 10 years the dairy processing sector has experienced mergers and consolidations; for example, Coca-Cola FEMSA (Fomento Económico Mexicano S.A) from Mexico acquired Estrella Azul; the cooperative Dos Pinos from Costa Rica acquired Nevada; and the company Casa Luker from Colombia acquired Bonlac. These recent developments have led to changes in the structure of the market, not only due to the increase in the size of operations, but also because of the type of products they demand.

Panama has traditionally been a net importer of dairy products. In 2013, the country imported about 112 million $\mathrm{kg}$ of FME units with a value of US\$104 million. From total imports, in terms of value, cheese accounted for 53 per cent, milk powder for 26 per cent, butter for 8 per cent, whey for 6 per cent, yogurt for 5 per cent and fluid milk and cream for 3 per cent. The export of dairy products from Panama has been relatively low; in 2013, the country exported about 22 million FME units with a value of US\$11.5 million; of this total 73 per cent was milk powder and 27 per cent was cheese. Due to tariff preferences obtained under the free trade agreement between Central America and Panama, dairy exports went mainly to Costa Rica, El Salvador, Guatemala, Honduras and Nicaragua.

\subsection{Analytical framework}

This study explores how to combine industrial organization (IO) and econometric research methods in price transmission analysis. With this aim, this research uses a three-step approach (Figure 1.2). First, we employ IO methods to analyse the structure of the milk market. Second, we use time-series econometrics to assess the price dynamics. Third, we 


\subsection{Chapter outlines}

\subsubsection{Chapter 1: Introduction}

In this section I describe the problem's relevance, an overview of the background knowledge, the context within which the research was done, the features of the analytical framework, and an outline of each chapter.

\subsubsection{Chapter 2: Spatial Price Transmission of Soaring Milk Prices from Global to Domestic Markets}

Milk has become one of the most volatile agricultural commodities in the international market. The high volatility of commodity prices and its implication for food security are clearly among the most important issues facing policy makers today. Thus, a deeper understanding of the magnitude, speed, and symmetry with which global milk prices are being transmitted to domestic prices at the farm gate level is a fundamental factor in the design of appropriate policy measures oriented to reduce not only the level of milk price volatility, but also poverty and food insecurity. The purpose of this chapter is therefore to assess the dynamics of the relationship between global and domestic milk prices.

The results of the spatial price transmission analysis indicate that in Panama a long-run cointegration relationship exists between global and domestic prices; however, only producers' prices show significant responses to price disequilibria. The output of the ECM shows that price swings in the global market are being transmitted to the domestic market but with a lower magnitude. Furthermore, the results of the AECM point out the potential presence of asymmetries in the transmission of milk prices from the global to the domestic market, indicating that increases in global prices tend to be transmitted faster to producers in Panama than decreases.

The semi-structured interviews with importers reveal that milk powder is imported using an auction system open exclusively to those processors holding an import licence. The import volume represents nearly 50 per cent of the total volume of industrial milk that processors demand every year. The quota is divided into two main parts: the first part, equivalent to 70 per cent of the quota, is negotiated in November, but physically imported in January during the dry season; the second part, equivalent to 30 per cent of the quota, is 
negotiated in May and internalized in July during the peak production season. However, if the international price is higher than the domestic price during the first term of the year, processors can request the government to allocate the full quota to the second term.

\subsubsection{Chapter 3: Vertical Price Transmission of Milk Prices: Are Small Dairy Producers Efficiently Integrated into Markets?}

The dairy sector in Panama has undergone significant changes in recent years. For example, the dairy industry has experienced mergers and consolidations that have led to increases in industry concentration, a decrease in the number of producers, and an increase in the scale of operations. Dairy producers have expressed concerns about the competitiveness of the dairy supply chain, arguing that price changes are not being transmitted efficiently from wholesalers to producers. This issue has captured special attention from policy makers due to its implications for welfare distribution, hence the need for policy intervention. In this context, this chapter examines the degree of vertical price transmission between wholesalers and small dairy producers to assess the efficiency level of the dairy market chain in Panama.

The result of the vertical price transmission analysis shows that a long-run single cointegration relationship exists between wholesalers' and producers' prices, where the direction of the price transmission tends to go from producers to wholesalers. A change in producers' prices does not have a significant effect on wholesalers' prices in the next period, and the speed at which prices tend to converge to fully correct for deviation is moderately slow. When producers' prices increase, the speed of adjustment tends to be significantly faster than when prices decrease; in other words, the transmission of prices is asymmetric.

The focus group discussion with producers reveals that in Panama milk prices increase during the dry season and decrease during the rainy season. Producers highlighted some of the factors that affect the level of price transmission: the presence of a large number of poorly organized dairy producers combined with a small number of well-articulated processors; a highly perishable product which restricts the geographic movement of raw milk; the fear of replacement or substitution by suppliers if they reduce their delivery quota; and a large proportion of fixed costs that prevent a reallocation of capital resources in the short run. 


\subsubsection{Chapter 4: Combining Industrial Organization and Econometric Methods in Price Transmission Analysis}

In Panama, the articles that appeared in various newspapers in 2007 suggesting that processors have agreed on the price of milk paid to producers, pointed out the lack of transparency in the milk market and motivated the national antitrust authority to open an investigation against industrial processors for the alleged use of monopolistic practices. The investigation found that four major processors exchanged information that ultimately led them to agree upon the purchase price of milk paid to producers. As a result, a fine was defined and an audit process established.

This chapter explores how to combine the use of industrial organization (IO) and econometric methods for price transmission analysis. Based on the literature review the analytical framework is guided by the following four propositions: (1) the milk market structure is characterized by oligopsonistic competition; (2) oligopsonistic power dampens the degree of price transmission; (3) incomplete price transmission is associated with market power; (4) the price spread narrows when markets become more competitive.

The results of the market structure analysis confirm the first proposition, highlighting that in Panama the milk market is characterized by an oligopsonistic structure constituted by six major processors and more than 6000 producers. The results of the VECM long-term parameter confirm our second proposition, indicating that in the long-run a change of 1 per cent in the wholesale price leads to a change of 0.45 per cent in the producer's price. The results of the semi-structured interviews with the national antitrust authority corroborate our third proposition, highlighting that four processors where found guilty of having incurred in collusion practices to fix the price of milk paid to producers. The VECM policy change dummy variable confirm our four proposition, showing that after antitrust regulations were imposed the price spread between wholesalers and producers decreased from 18 per cent to 12 per cent.

Finally, the results of the semi-structured interviews and focus group discussions corroborate our four propositions, highlighting that the combination of a high level of market concentration at the industry level with an inelastic price supply function at the producer level has allowed market power to emerge and affect the level of price transmission. 


\subsubsection{Chapter 5: Conclusions}

Finally, in this chapter, I present a summary of the main outcomes of the research, the conclusions of the papers written and published along the way; and the research's main contribution. At the end of this section, I do a looking back and looking forward assessment, describing the major steps during my research process, what I have learned, some areas for potential improvement, and topics for future research in this field.

\subsection{Compilation of articles}

The three articles which form the core of this thesis are:

- Acosta, A., Ihle, R., \& Robles, M. 2014. Spatial Price Transmission of Soaring Milk Prices from Global to Domestic Markets. Agribusiness, 30: 64 - 73. doi:10.1002/agr.21358

- Acosta, A. \& Valdés, A. 2014. Vertical Price Transmission of Milk Prices: Are Small Dairy Producers Efficiently Integrated into Markets? Agribusiness, 30: 56 - 63. doi:10.1002/agr.21357

- Acosta, A., Ihle, R., \& Valdés, A. 2016. Combining Industrial Organization and Econometric Methods in Price Transmission Analysis. This article has been submitted for review. 


\section{References}

Abdulai, A. 2000. Spatial price transmission and asymmetry in the Ghanaian maize market. Journal of Development Economics, 63(2): 327-349

Amikuzuno, J. \& von Cramon-Taubadel, S. 2012. Seasonal variation in price transmission between tomato markets in Ghana. Journal of African Economies, 21(4): 669-686.

Awokuse, T. \& Wang, X. 2009. Threshold effects and asymmetric price adjustments in U.S. dairy markets. Canadian Journal of Agricultural Economics, 57(2): 269-286.

Bakucs, Z., Fałkowski, J. \& Fertő, I. 2014. Does market structure influence price transmission in the agro-food sector? A meta-analysis perspective. Journal of Agricultural Economics, 65: 1-25.

Bekkerman, A., Goodwin, B. \& Piggott, N. 2013. A variable threshold band approach to measuring market linkages. Applied Economics, 45(19): 2705-2714.

Bolotova, Y.V. \& Novakovic, A.M. 2012. The impact of the New York state milk price gouging law on the price transmission process and supermarket pricing strategies in the fluid whole milk market. Agribusiness, 28(4): 377-399.

Brümmer, B., von Cramon-Taubadel, S. \& Zorya, S. 2009. The impact of market and policy instability on price transmission between wheat and flour in Ukraine. European Journal of Agricultural Economics, 36(2): 203-230.

Busse, S., Brümmer, B. \& Ihle, R. 2012. Price formation in the German biodiesel supply chain: a Markov-switching vector error-correction modeling approach. Agricultural Economics, 43(5): 545-560.

CGRP (Contraloría General de la República de Panamá). 2011. VII censo nacional agropecuario, 2011. Resultados finales, Ciudad de Panamá.

Dawe, D., Morales-Opazo, C., Balie, J., \& Pierre, G. (2015). How much have domestic food prices increased in the new era of higher food prices?. Global Food Security, 5, 1-10.

Dawe, D., \& Maltsoglou, I. 2014. Marketing margins and the welfare analysis of food price shocks. Food Policy, 46, 50-55.

Engel, R. \& Granger, C. 1987. Cointegration and error correction: representation, estimation, and testing. Econometrica, 55(2): 251-276.

Enders, W. 1998 Applied econometric time-series. John Wiley \& Sons, Inc.

Frey, G. \& Manera, M. 2007. Econometric models of asymmetric price transmission. Journal of Economic Surveys, 21(2): 349-415.

Goodwin, B.K. \& Holt, M.T. 1999. Price transmission and asymmetric adjustment in the US beef sector. American Journal of Agricultural Economics, 81(3): 630-637 
Goodwin, B.K. \& Vavra, P. 2009. What can we learn from spatial and vertical price transmission studies?. Empirical examples from U.S. meat markets. Paper prepared for the Courant Research Centre $\backslash$ Poverty, Equity and Growth" Inaugural Conference at the University of Gottingen, Germany.

Götz, L., Glauben, T., \& Brümmer, B. 2013. Wheat export restrictions and domestic market effects in Russia and Ukraine during the food crisis. Food Policy 38: 214-226.

Granger, C. 1981. Some properties of time-series data and their use in econometric model specification. Journal of Econometrics, 16(1): 121-130

Granger, C. \& Lee, T. 1989. Investigation of production, sales and inventory relationships using multicointegration and non-symmetric error correction models. Journal of Applied Econometrics, 4: 145-159

Hassouneh, I., Serra, T. \& Gil, J.M. 2010. Price transmission in the Spanish bovine sector: the BSE effect. Agricultural Economics, 41(1): 33-42

Hassouneh, I., Serra, T., Goodwin, B \& Gil, J. M. 2010. Non-parametric and parametric modelling of biodiesel, sunflower oil, and crude oil price relationships. Energy Economics, 34(5): 1507-1513.

Ihle, R., Brümmer, B. \& Thompson, S.R. 2012. Structural change in European calf markets: decoupling and the blue tongue disease. European Review of Agricultural Economics, 39(1): 157-180.

INEC (Instituto nacional de estadística y censo de Panama). 2014. Estimacion de la produccion de leche de vaca en la Republica de Panama: 1993-2013

Kinnucan, H. W. \& Zhang, D. 2015. Notes on farm-retail price transmission and marketing margin behaviour. Agricultural Economics, 46: 729-737.

Lloyd, T., McCorriston, S., Morgan, W., \& Rayner, T. 2004. Price transmission in imperfectly competitive vertical markets. Discussion Papers in Economics, (04/09), 1-19.

McCorriston, S. 2013. Transparency of Food Pricing. TRANSFOP. Paper prepared as the OECD Secretariat background paper for the OECD Competition Roundtable in Paris for the special session on "Competition in the Food Chain"

McLaren, A. 2015. Asymmetry in price transmission in agricultural markets. Review of Development Economics, 19(2): 415-433.

Meyer, J. \& von Cramon-Taubadel, S. 2004. Asymmetric price transmission: a survey. Journal of Agricultural Economics, 55(3): 581-611.

MIDA. Ministerio de Desarrollo Agropecuario. 2011. Resolución DAL No. 018-ADM2011. Gaceta Oficial. Panama, Mayo, 2011.

Miller, D.J. \& Hayenga, M.L. 2001. Price cycles and asymmetric price transmission in the U.S. pork market. American Journal of Agricultural Economics, 83(3): 551-562.

Serra, T. \& Goodwin, B.K. 2002. Price transmission and asymmetric adjustment in the Spanish dairy sector. 2002 Annual meeting, 28-31 July, Long Beach, California, American Agricultural Economics Association. 
Sexton, R.J. \& Lavoie, N. 2001. Food processing and distribution: an industrial organization approach. Handbook of agricultural economics, 1: 863-932.

von Cramon-Taubadel, S. 1998. Estimating asymmetric price transmission with the error correction representation: an application to the German pork market. European Review of Agricultural Economics, 25(1): 1-18.

Yin, R. 2013. Case study research: design and methods. London, Sage publications, Inc. 



\title{
Chapter 2 Spatial Price Transmission of Soaring Milk Prices from Global to Domestic Markets
}

\begin{abstract}
Milk has become one of the most volatile agricultural commodities in the international market. High volatility of commodity prices and their implications for food security are clearly among the most important issues facing policy makers today. Thus, a deeper understanding of the magnitude, speed, and symmetry to which global milk prices are being transmitted to domestic prices at the farm gate level is a fundamental factor in the design of appropriate policy measures oriented to reduce not only the level of milk price volatility, but also poverty and food insecurity. The purpose of this chapter is therefore to assess the dynamics of the relationship between global and domestic milk prices.
\end{abstract}

\subsection{Introduction}

Milk has become one of the most volatile agricultural commodities in the world (IFCN, 2010) due to multiple independent phenomena affecting its availability and demand over a short period of time. According to FAO, the international market price of dairy products has doubled, halved, and doubled again over the last five years. For example, the FAO's international index for dairy products increased 100 per cent between November 2006 and November 2007, when it reached a record value of 268, the most significant price spike in recent history (FAO, 2008). The causes of this spike were primarily attributed to the exhaustion of public stocks in the European Union and the sharp increase in feed prices in 2007 caused by short global supplies and high feed grain demand for biofuel (FAO, 2007). However by the end of 2008, dairy prices started falling again at an accelerated rate, with the index reaching a value of 159 in November. This decrease was related to the increased availability of dairy products in the international 
market, the value of the dollar, the melamine contamination of milk supplies in China, and especially the global economic crisis (FAO, 2008).

After the marginal contraction in demand experienced in 2008, prices of dairy products jumped again in late 2009, and the index reached a value of 208 in November as speculation about other food crises and risk uncertainty led to stock retention, causing a 32 per cent rise in November alone (FAO, 2009). In addition, the contraction of supply from Oceania and lively import demand from Asia contributed to an upsurge in dairy prices experienced in 2010. Modest production response in exporting countries, unfavourable climate conditions, and policies such as those in the EU that limit output caused prices to jump again during the first quarter of 2011 (however, since the second quarter prices have trended downwards).

This increase in price volatility is no longer perceived as a temporary phenomenon, but as the new trend of global markets (FAO, 2010). Such volatility has raised serious concerns, not only among producers and consumers but also among policy makers who are trying to design policy measures other than traditional market tools to lessen price swings (FAO, 2008). Among the structural factors that have contributed to the phenomenon of milk price volatility are: a) the strong influence that small changes of quantity in the milk market have on price; b) the slow speed of adjustment of domestic milk production as a result of price changes (low price elasticity of supply); c) the delayed reaction of demand to changing dairy commodity prices (low price elasticity of demand) and d) the weak vertical transmission of price signals from consumers to producers (FAO, 2010).

Milk price volatility is causing different effects among countries and socioeconomic groups. On the one hand, milk soaring prices is benefiting net exporting countries and producers that react quickly to new market trends. On the other, it is negatively affecting net importing developing countries such as Panama by deteriorating their terms of trade. When international milk prices increase in countries like Panama, the cost of the food basket goes up, reducing the real income of net food buyers. However, when international milk prices decrease, the income of dairy producers - particularly that of small producers that compete with industrial milk quality — is seriously affected.

Ensuring a competitive price level at the farm gate is one of the keys to agricultural growth and thus poverty reduction (Norton, 2004). Therefore, a better understanding of the extent to which global milk prices are being efficiently transmitted to producers at the farm gate level is an important issue for the design of policy measures aimed at decreasing not only the level of 
price volatility, but also poverty and food insecurity (Schroeder \& Hayenga 1987). The purposes of this document are: i) to analyse if small dairy producers and global milk markets are integrated; ii) to estimate whether changes in global milk prices are being efficiently transmitted to small dairy producers' prices at the farm gate level; and iii) to assess the dynamics of the relationship between global and domestic milk prices.

\subsection{Characteristics of the dairy trade market in Panama}

Panama entered the WTO in 1996 and negotiated a milk import quota of 12,000 metric tons per year of fluid milk equivalents. Prior to 1996, it maintained a dynamic milk production growth rate of $7.2 \%$ per year. However, after this period, milk production growth decreased drastically to an average rate of $1.3 \%$ per year. This sudden change has been partially explained by the fact that growth in demand came to be fulfilled through increments in import volumes rather than increased national production. As shown in table 2.1, in 2009 Panama produced about 168 million liters of fluid milk equivalents (FME), imported 130 million, and exported 17 million. Thus the total availability of milk was about 281 million liters of fluid milk equivalents and the dependency ratio $46 \%$. The average consumption per capita per year is 98 liters.

Table 2.1 Milk availability and consumption in Panama 2000 - 2009 (*Million liters)

\begin{tabular}{|c|c|c|c|c|c|c|c|c|c|c|}
\hline Description & 2000 & 2001 & 2002 & 2003 & 2004 & 2005 & 2006 & 2007 & 2008 & 2009 \\
\hline Production * & 153.8 & 152.5 & 155.6 & 158.2 & 154.8 & 160 & 159.7 & 164.2 & 164.5 & 168.5 \\
\hline Imports* & 102.3 & 96.1 & 97.5 & 103.1 & 84.4 & 123.4 & 110.6 & 127.6 & 164.5 & 130.2 \\
\hline Exports* & 24.8 & 25.4 & 27.1 & 17.1 & 22 & 25 & 18.7 & 17.7 & 21.8 & 17.4 \\
\hline Apparent demand* & 231.3 & 223.2 & 226 & 244.2 & 217.2 & 258.4 & 251.6 & 274.1 & 307.2 & 281.3 \\
\hline Consumption Lt/cap & 77 & 72.9 & 72.4 & 76.8 & 67.1 & 78.4 & 75 & 80.3 & 88.5 & 79.7 \\
\hline Dependency ratio (\%) & 44.2 & 43.1 & 43.1 & 42.2 & 38.9 & 47.8 & 44 & 46.6 & 53.5 & 46.3 \\
\hline
\end{tabular}

Source: Ministerio de Desarrollo Agropecuario de Panamá (2011); Contraloría General de la Republica (2011)

Panama has traditionally been a net importer of dairy products. In 2009, the total quantity of imports was about 17 million liters, with a value of 62 million dollars. Ninety per cent of these imports consist of raw materials used for industrial purposes such as whole milk powder, skim milk powder, and cheddar cheese. The remaining $10 \%$ is used for finished products such as 
fluid milk, evaporated milk, condensed milk, and fresh cheese. Most imports of milk products come from Oceania.

The dairy import market in Panama is characterized by a high level of nominal protection. The dairy product with the highest import duty is evaporated milk, with an average tariff of $155 \%$, followed by fluid milk with a tariff of $60 \%$, and milk powder with a tariff of $50 \%$. The import tariff applied to other dairy products ranges from zero to $30 \%$. However since most of the dairy products imported come either from the WTO tariff rate quota or are entered under the Most Favoured Nation (MFN) tariff scheme, the real tariffs applied to dairy imports are significantly lower than the nominal rate. In fact, statistics from the National Customs Authority shows that the average import duties applied to dairy products in 2008, 2009, and 2010 were $5.7 \%, 7.4 \%$ and $6.2 \%$ respectively. (FAO, 2012).

The export of dairy products in Panama is very limited, accounting less than 18 million liters in 2009. Due to tariff preferences obtained with the signature of the Free Trade Agreement, about $90 \%$ of Panama's dairy exports are sold to Central American countries. During 2009 dairy exports went to Costa Rica (68\%), Honduras (10\%), Guatemala (9\%), Nicaragua (8\%), and El Salvador (5\%). In terms of the total value, most of these exports were in the form of cheese (42\%), evaporated milk (34\%), and condensed milk (24\%) (CGR, 2011).

\subsection{Spatial price transmission analysis}

Spatial price transmission refers to the process based through which markets for a homogeneous commodity at spatially separated locations share long-run information ( $\mathrm{McNew}$, 1996; Fackler and Goodwin, 2001). Spatial price transmission has been widely analysed in the context of the "Law of One Price" which hypothesizes that if two markets are linked by trade and are efficient, the price differential between them is equal to the cost of carrying out trade between them (transaction costs) (Fackler and Goodwin, 2001). Prices are consequently thought of being connected by a stable long-run equilibrium, with attraction forces of this equilibrium resulting in the correction of temporal deviations that occur due to supply or demand shocks. Therefore, a proportional increase in the international price of an agricultural commodity will lead to an equally proportional increase of its price in domestic markets, at all points in time, assuming markets are perfectly integrated (Mundlak and Larson, 1992). In this 
context, price transmission analysis measures the extent and the speed to which price shocks are transmitted between spatially separated locations (Amikuzuno 2009).

According to Rapsomanikis et al. (2003), the notion of price transmission can be better understood as being based on three main components: 1) co-movement and completeness of adjustment, 2) dynamics and speed of adjustment, and 3) asymmetry of response. Comovement and completeness of adjustment entails that a change in the price of an agricultural commodity in one market is reflected in the price change of the commodity in other markets. Dynamics and speed of adjustment relates to the process and rate at which changes in prices in one market are transmitted to other markets. Asymmetry of response refers to the process in which transmission differs according to whether the prices are increasing or decreasing (von Cramon-Taubadel 1998; Prakash 1999; Balcome and Morrison 2002; Rapsomanikis et al 2003; Meyer and von Cramon-Taubadel 2004).

The literature on spatial price transmission has dealt with various factors that constrain the pass-through of price signals from one market to another (see Meyer and von Cramon-Taubadel 2004 for an overview). For better understanding, we classify these factors into three main groups: transaction costs, trade policies, and market power.

- Transaction costs: In many cases, particularly in developing countries where infrastructure is of poor quality, transaction costs are markedly increased or prohibitively high. In combination with deficient communication services, this results in, high transport costs that make arbitrage expensive and links markets insufficiently (Abdulai 2000; Conforti 2004);

- Trade policies: Import tariffs, tariff rate quotas, export subsidies, export taxes, and exchange rate policies can isolate domestic markets and obstruct the full transmission of international price signals. The higher tariff levels are, the closer domestic prices will be to autarky and the less international price changes will be transmitted to national markets (Rapsomanikis et al. 2003, Conforti, 2004);

- Market power: Imperfect competition due the concentration of market power on actors at one or more levels of the supply chain might result in an incomplete, low, and asymmetric pass-through of prices. This implies higher price differences between markets than can be attributed to transaction cost hindering the transmission of market signals (Abdulai 2000, Rapsomanikis 2003); 
Most of the models applied to analyse spatial price transmission are based on the log-linear regression model (1) used by Mundlak and Larson (1992) to assess the relationship between international and domestic prices. This work was criticized and proved wrong by Quiroz and Soto (1995). Furthermore, Ardeni (1989) has argued that many of the previous studies conducted in the area of market integration and price transmission were unreliable, and that most of the evidence presented to support the assumption that commodity prices are cointegrated in the long-run was flawed and affected by spurious regressions, non-stationary series, or inappropriate use of first differences. In order to deal with these econometric shortcomings, he proposed a new methodological alternative approach based on cointegration theory.

Balcombe et al. (2007) pointed out that regular cointegration approaches often ignore the important role played by transaction costs. They assume a linear relationship between prices that are inconsistent with discontinued trade and possesses weak power to discriminate between integrated and independent markets. Furthermore, Goodwin and Piggot (2001) have highlighted that transaction costs may result in a neutral band within which markets are well integrated even though prices are not directly linked. Acknowledgment of the importance of this issue has led to the application of new empirical approaches that explicitly recognize the influence of transaction costs on spatial price transmission. On this subject, several authors (Abdulai, 2000; Balcombe, 2007, Goodwin, 2001) have found threshold vector error correction models (TVECM) sufficient to examine spatial price transmission issues taking into account transaction costs.

Nevertheless, as indicated by Meyer \& von Cramon-Taubadel (2004), a major shortcoming in TVECM models is that they are based on the assumption that transaction costs are constant an assumption that is not valid in Panama, since transaction costs in the milk market change constantly depending on factors such as the level of the import duty and size of the import quota. In this regards, Acosta (2012) found the use Asymmetric Error Correction Models (AECM) to be a good alternative econometric approach to conduct a spatial price transmission analysis when transaction cost is not constant. 


\subsection{Econometric methods}

Regressions involving nonstationary time-series will produce spurious results showing a significant relationship between variables that appear correlated, but not related to each other. Therefore, the first step in our price transmission analysis was to determine whether the timeseries contained a unit root. However, the reliability of a unit root test is highly dependent on the selection of a model that mimics the actual data generation process, since the critical values of the t-statistics are influenced by whether or not an intercept and/or any time trend is included in the regression equation. The addition of an extra parameter reduces the degree of freedom, thus making the power of the unit root test go to zero and leading to misspecification errors (Type I error) in which the null hypothesis of unit roots is wrongly rejected (Enders 2005). Therefore, in order to determine whether or not to include a deterministic element in the regression, we ran three different types of regression equations.

$$
\begin{gathered}
\Delta y_{t}=a_{0}+\gamma y_{t-i}+a_{2} t+\sum_{i=2}^{p} \beta_{i} \Delta y_{t-i+1}+\varepsilon \\
\Delta y_{t}=a_{0}+\gamma y_{t-i}+\sum_{i=2}^{p} \beta_{i} \Delta y_{t-i+1}+\varepsilon_{t} \\
\Delta y_{t}=\gamma y_{t-i}+\sum_{i=2}^{p} \beta_{i} \Delta y_{t-i+1}+\varepsilon_{t}
\end{gathered}
$$

The first equation (2.1) was an unrestricted model that included both an intercept and a linear time trend. For the second equation (2.2), we restricted the trend. The third equation (2.3) was a random walk model that restricted both the trend and the intercept chosen (Dickey and Fuller 1979, 1981 quoted by Enders 2005). Afterwards, an Augmented Dickey Fuller (ADF) test was used to test for unit roots. Given that all the time-series analysed were non-stationary, and taking co-integration theory into account (which says that two or more non-stationary series are long-term cointegrated if both series are integrated of the same order and their linear combination yields a disturbance term that is stationary), we followed a Johansen (1991) approach to test the null hypothesis of non-cointegration against the alternative hypothesis of cointegration. 
Taking into account that both of the time-series analysed were cointegrated, we estimated an Asymmetric Vector Error Correction Model (AVECM) in order to shed light on the interdependencies of both prices. We followed the two-step approach proposed by Engel and Granger (1987) to capture the short-term effects, and the speed of adjustment at which a dependent variable returns to equilibrium after a change in an independent variable. However, we adapted it by modifying the first step and estimating the long-run price equilibrium by using Johansen's (1991) reduced rank regression, since it was shown to be superior in most contexts by Gonzalo (1994). In the first step, we estimated equation (2.4) regressing producer prices (PP) on global prices (GP) to obtain an estimate of the residuals (ect), which quantify the deviations from the long-run equilibrium often referred to as error correction terms. As a second step, we estimated equation (2.5) regressing $\mathrm{P}$ on lags of itself, and $\mathrm{P}$ and the lagged equilibrium errors (ect).

$$
\begin{gathered}
P P_{t}=\beta_{0}+\beta_{1} G P_{t}+e c t_{t} \\
\Delta p_{t}=\alpha e c t_{t-1}+\sum_{j} \gamma_{j} \Delta p_{t-j}+\varepsilon_{t}
\end{gathered}
$$

The coefficient $\gamma$ capture the short-term effects of the lags of the changes of both prices $p_{t}=\left(G P_{t} P P_{t}\right)^{\prime}$ on Panama price movements in the current period, and $\alpha$ quantifies the rate at which the domestic prices adjust equilibrium deviations after a shock — in other words, the error correction term (ect).

$$
\Delta p_{t}=\alpha^{+} e c t_{t-1}^{+}+\alpha^{-} e c t_{t-1}^{-}+\sum_{j} \gamma_{j} \Delta p_{t-j}+\varepsilon_{t}
$$

Finally we follow the approach proposed by von Cramon-Taubadel (1998) and test for asymmetries in the transmission of price signals. The AVECM, denoted in (2.6), is obtained by splitting the error correction term $e c t_{t-1}$ into its positive and negative parts so that a separate evaluation of responses to non-negative $\left(e c t_{t-1}^{+}\right)$and negative $\left(e c t_{t-1}^{-}\right)$deviations from the longrun equilibrium becomes possible. This allows one to identify whether the speed at which prices are transmitted differ, depending on the direction of the price changes - in other words whether price transmission is asymmetric. 


\subsection{Data}

The spatial price transmission analysis was conducted using 144 monthly price observations over the period 2000 (1) to 2011 (12). Figure 2.1 presents the plot of the data. For the domestic market we used producer monthly milk price observations at the farm gate level reported by the Contraloria General de la Republica in Panama. For the international market, we used F.O.B. Oceania whole milk powder monthly prices reported by the USDA Dairy Market News. For comparison purposes, fluid milk producer prices were transformed into whole milk powder prices using a conversion factor of 8.3, as suggested by Angeles-Montiel et al (2004).

Figure 2.1 Global and domestic milk prices

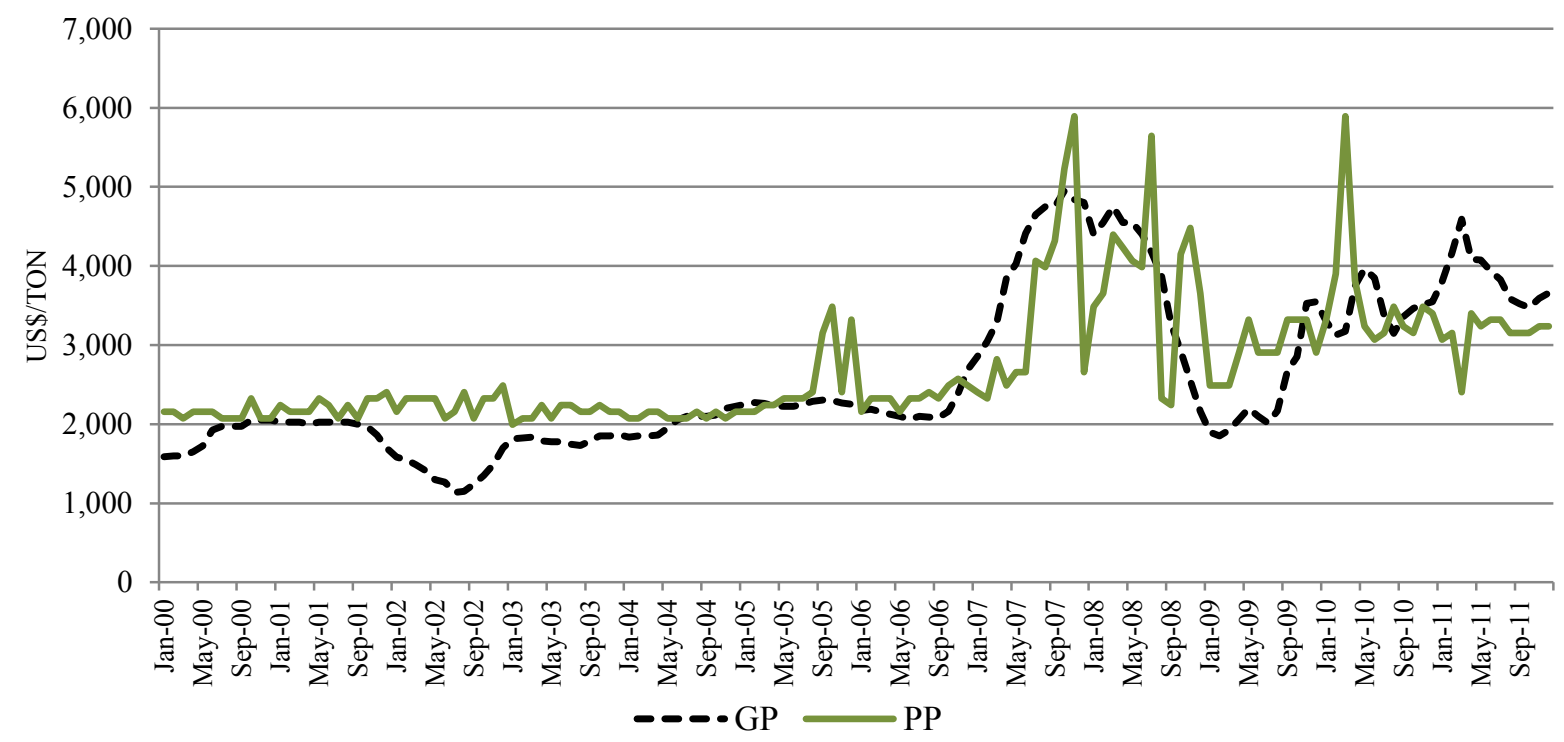

Source: International whole milk powder prices (Oceania, indicative F.O.B export prices ) reported by the United States Department of Agriculture Dairy Market News (USDA, 2012); and Producers fluid milk monthly prices at the farm gate reported by Contraloría the General de la Republica de Panamá (CGRP, 2012).

\subsection{Results}

The model specification procedure facilitated the identification of the equation that best simulates the data generating process. The output (Table 2.2) indicates that for the Producer Price (PP) model, the coefficients associated with the constant $\left(a_{0}\right)$ and trend parameter $\left(a_{2}\right)$ are significant at the 5 per cent level, suggesting that adding these two variables to the equation significantly improves the explanatory power of the model, a result that is confirmed by the F- 
test statistic (14.02), a result that is superior to the critical value of $F(1.120)$ at the 1 per cent level (6.85).

On the other hand, the regression results of the Global Price (GP) model shows that the coefficient of the constant parameter is significant at the 5 per cent level, whereas the coefficient of the trend parameter is not - results that are confirmed by the value of the F-test (3.93) which is inferior to the critical value of the F-test at the 1 per cent level, suggesting that the addition of the time trend parameter does not significantly improve the explanatory power of the model.

Table 2.2 Model specification

\begin{tabular}{cccccc}
\hline Model & $a_{0}$ & $a_{2}$ & $\gamma$ & $\beta_{t-p}$ & F-test \\
\hline$\Delta p p_{t}=a_{0}+a_{2} t+\gamma p p_{t-i}+\sum_{i=1}^{p} \beta_{i} \Delta p p_{t-i}+\varepsilon_{t}$ & 860.86 & 5.56 & -0.45 & -0.03 & 14.02 \\
$\Delta g p_{t}=a_{0}+\gamma g p_{t-i}+\sum_{i=1}^{p} \beta_{i} \Delta g p_{t-i}+\varepsilon_{t}$ & $(4.80)$ & $(3.71)$ & $(-5.52)$ & $(-0.42)$ & \\
& & & & & \\
& $(1.92)$ & - & -0.02 & 0.49 & 3.93 \\
\hline
\end{tabular}

Source: Authors

In order to test for the presence of unit roots, an Augmented Unit Root Test (ADF) was used (Table 2.3). The optimal number of lags was determined using the Schwarz Criterion information criteria. The outputs of the unit root tests indicate that for both variables there is insufficient evidence to reject the null hypothesis of unit roots at the 5 per cent level, suggesting that both series appear to be non-stationary processes and integrated of order one.

Table 2.3 Unit Root Tests

\begin{tabular}{cccccc}
\hline Variable & Lags & $H o: \gamma=0$ & Lags & $H o: \Delta \gamma=0$ critical values at $5 \%$ level \\
\hline PP & 3 & -3.27 & 7 & -11.59 & -3.41 \\
GP & 1 & -1.84 & 0 & -6.98 & -2.86 \\
\hline
\end{tabular}

Source: Authors

Considering that both series are I (1) processes, a Johansen Trace Test was used to determine if the time-series are cointegrated, that is, whether they share a long-run equilibrium. It is unlikely that there will be a trend in the cointegrating relationship between the series. Thus we assume that the models contain an intercept, but not a time trend. The results of the Johansen's 
Test (Table 2.4) indicate that there is strong evidence to reject the null hypothesis of no cointegration between GP and PP, suggesting that a long-run cointegration relationship exists between global and producer prices.

Table 2.4 Johansen Trace Test

\begin{tabular}{cccccc}
\hline Variable & Lags & Ro & LR & P-Value & critical values at 5\% level \\
\hline GP & 2 & 0 & 51.49 & 0.00 & 24.69 \\
PP & 0 & 1 & 4.24 & 0.38 & 12.53 \\
\hline
\end{tabular}

Source: Authors

The output of the ECM in equation (2.7) shows the existence of a long-run equilibrium between global and domestic milk prices, however it also indicates that prices changes in global market are buffered in the domestic market, since the coefficient of $G P_{t}$ is smaller than unity.

$$
P P_{t}=1175+0.605 G P_{t}+e c t_{t}
$$

The results of the AECM (equation 2.8) illustrate first, that only producer prices respond to disequilibria, since both coefficients of the global price are not significant at the $5 \%$ level. Second, the producer price reacts faster to positive disequilibria than to negative ones. Third, the correction of price disequilibria is of a very strong magnitude and coefficients are of the correct sign. Hence, a stretched margin $e c t_{t}^{+}$which can either be caused by increased domestic prices or decreased global prices is transmitted to producers faster than squeezed margins $e c t_{t}^{-}$ which can either be caused by decreased domestic prices or higher than equilibrium global prices.

$$
\begin{aligned}
& \left(\begin{array}{l}
\Delta P P_{t} \\
\Delta G P_{t}
\end{array}\right)=\left(\begin{array}{c}
-0.81 * * * \\
\underset{(-4.76)}{-0.02} \\
(-0.31)
\end{array}\right) e c t_{t-1}^{+}+\left(\begin{array}{c}
-0.49^{* *} \\
(-2.28) \\
-\underset{(-1.88)}{0.12^{*}}
\end{array}\right) e c t_{t-1}^{-}
\end{aligned}
$$

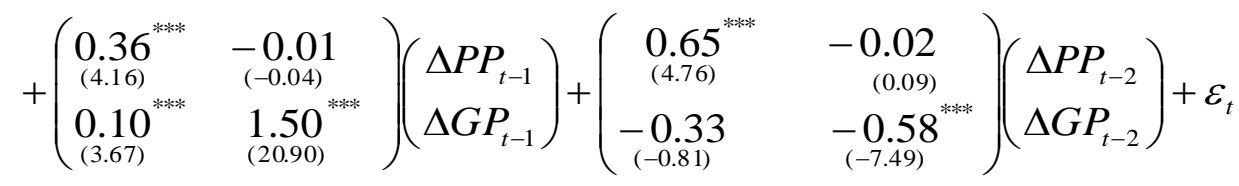

The results point to pronounced asymmetry, where trade institutions and trade infrastructure (which link domestic Panamanian producers to the global market) transmit decreases in global 
market prices faster to producers than they transmit global market increases. However, an Ftest on the hypothesis that the coefficients of the responses to positive and negative disequilibria do not differ significantly (that is, that there is no asymmetry) and could not be rejected at the $5 \%$ level since the test statistic of 1.55 is considerably smaller than the critical value of 3.84. The analysis therefore provides no robust statistical evidence for asymmetry in price responses although the numerical estimates differ considerably.

Finally, the semi-structured interviews with importers reveal that milk powder is imported using an auction system open exclusively to those processors holding an import license. The import volume represents nearly 50 per cent of the total volume of industrial milk that processors demand every year. The quota is divided into two main parts: the first part, equivalent to 70 per cent of the quota, is negotiated in November, but physically imported in January during the dry season; the second part, equivalent to 30 per cent of the quota, is negotiated in May and internalized in July during the peak production season. However, if the international price is higher than the domestic price during the first term of the year, processors can request the Government to allocate the full quota to the second term. The results of the semi-structure interviews suggest that the import quota mechanism is obstructing a more complete and symmetric transmission of internal price signals.

\subsection{Conclusion}

The findings of the econometric analysis indicate that a long-run cointegration relationship exists between global and domestic producers' prices, however only producers prices show significant responses to price disequilibria, which appears to be plausible due to the relative sizes of both markets. The output of the ECM shows that price swings in global market are being transmitted to domestic markets in Panama, but with a lower magnitude. Furthermore, the results of the AECM point out the potential (although statistically weak evidence) presence of asymmetric price transmission of global and domestic milk prices, indicating that increases in global prices tend to be transmitted faster to producers than decreases. The results of the semi-structure interviews suggest that the import quota mechanism is obstructing a more complete and symmetric transmission of price signals from international to domestic markets. Based on these results, we conclude that a large part of producer's milk prices changes in Panama are driven more by domestic rather than international conditions. 


\section{References}

Acosta, 2012. Measuring Spatial Transmission of White Maize Prices between South Africa and Mozambique: An Asymmetric Error Correction Model Approach. African Journal of Agricultural and Resource Economics, Vol 7, No. 1. Dec., 2012.

Acosta, A., Valdés, A. Perspectivas Económicas del Sector Ganadero en Centroamérica y Desafíos de Política. Documento de Trabajo. Oficina Subregional de la FAO para América Central.

Abdulai A, 2000. Spatial Price Transmission and Asymmetry in the Ghanian Maize Market. Journal of Development Economics (63): 327-349.

Amikuzuno J, 2009. Spatial Price Transmission and Market Integration in Agricultural Markets after Liberalization in Ghana: Evidence from Fresh Tomato Market. Ph D Dissertation, Department of Agricultural Economics and Rural Development, Faculty of Agricultural Sciences, Georg-August-Universität Göttingen, Germany.

Angeles-Montiel, R., Mora, J., Martínez, M., García, R. 2004. Efecto de las Importaciones de Leche en el Mercado Nacional del Producto. Agrociencia, Colegio de Posgraduados Texcoco, México. Vol. 38, No 005. Septiembre-Agosto, 2004, pp 555-564.

Ardeni, P (1989). Does the Law of One Price Really Hold for Commodity Prices?. American Journal of Agricultural Economics, Vol. 71, No. 3. Aug., 1989, pp. 661-669

Balcombe K, Morrison J, 2002. Commodity Price Transmission: A Critical Review of Techniques and an Application to Selected Tropical Export Commodities. Report prepared for FAO ESCR. FAO Economic and Social Development Department, Rome, Italy.

Balcome K, Bailey A, Brooks J, 2007. Threshold Effects in Price Transmission: The Case of Brazilian Wheat, Maize and Soya Prices. American Journal of Agricultural Economics 89(2): 308-323.

Conforti P, 2004. Price Transmission in Selected Agricultural Markets. Working Paper No. 7, FAO Commodity and Trade Policy Research.

Contraloría General de la República de Panamá (CGRP). (2012). Base de datos sobre precios de alimentos de la canasta basica nacional. Ciudad de Panamá, Octubre del 2012.

Dougherty C, 2007. Introduction to Econometrics. Third Edition, Oxford University Press, New York.

Enders, W, 2005. Applied Econometric Time-series . 2nd Edition. New York: John Wiley and Sons. Harris, R. 1995. Using Cointegration

Engel R, Granger C (1987). Co-integration and Error Correction: Representation, Estimation and Testing. Econometrica 55(2): $251-276$.

Fackler, P.L., and B.K. Goodwin (2001). "Spatial Price Analysis." In B. Gardner, and G. Rausser (eds): Handbook of Agricultural Economics, Vol. 1, Elsevier, Amsterdam, The Netherlands, pp. 971-1024. 
FAO, 2007. Food Outlook: Global Market Analysis. November, 2007

FAO, 2008. Food Outlook: Global Market Analysis. November, 2008

FAO, 2009. Food Outlook: Global Market Analysis. November, 2009

FAO, 2009. The State of Food Insecurity in the World: Economic Crises - Impacts and Lessons Learned.

FAO, 2010. Food Outlook: Global Market Analysis. November, 2010

FAO, 2010. Status and Prospects for Smallholder Milk Production - A Global Perspective, by T. Hemme and J. Otte. Rome. .

FAO, 2011. Food Outlook: Global Market Analysis. November, 2011

Gonzalo, J 1994. Five Alternative Methods of Estimating Long-run Equilibrium Relationships. Journal of Econometrics 60: 203-233.

Goodwin B, Piggott N, 2001. Spatial Market Integration in the Presence of Threshold Effects. American Journal of Agricultural Economics 83(2): 302-317.

IFCN (2010). Dairy Report 2010. IFCN Dairy Research Center at CAU Kiel, Faculty of Agricultural and Nutritional Sciences, Germany. November, 2010.

Ihle R, von Cramon-Taubadel S, Zorya S 2009. Markov-Switching Estimation of spatial Maize Price Transmission Processes between Tanzania and Kenya. American Journal of Agricultural Economics 91(5): 1432 - 1439.

Johansen S, 1991. Estimation and Hypothesis Testing of Co-integration Vectors in Gaussian Vector Autoregressive Models. Econometrica 59(6): 1551 - 1580.

McNew K, 1996. Spatial Market Integration: Definition, Theory, and Evidence. Agricultural and Resource Economics Review 25(1): 1-11.

Meyer J, von Cramon-Taubadel S, 2004. Asymmetric Price Transmission: A Survey. Journal of Agricultural Economics, Blackwell Publishing 55(3): 581 - 611.

Mundlak Y, Larson D,E, 1992. "On the Transmission of World Agricultural Prices". The World Bank Economic Review 6(3): 399-422.

Norton, R 2004. Agricultural Development Policy. Concepts and Experiences: Concepts and Experiences. Food and Agricultural Organization of the United Nations.

Okello, J (2009). The 2007-2008 Food Price Swing: Impact and Policies in Kenya. University of Nairobi, Department of Economics. Discussion Paper. Project on Policies for Good Economic Management of Food Price Swings in Africa. FAO Trade and Market Division. March 2009.

Prakash A, 1999. The Transmission of Signals in a Decentralized Commodity Marketing System. The case of the UK Pork Market, PhD Dissertation, Wye College, University of London. 
Rapsomanikis G, Hallam D, Conforti P, 2003. Market Integration and Price Transmission in Selected Food and Cash Crop Markets of Developing Countries: Review and Applications. In Commodity Market Review 2003-2004. FAO, Rome.

Schroeder T, Hayenga M. (1987). Short-term vertical market price interrelationships for beef and pork. North Central Journal of Agricultural Economics 9: 171-190.

USDA, 2012. United States Department of Agriculture. Agricultural Marketing Services. Dairy Market Statistics. http://www.marketnews.usda.gov/portal/da Accessed 1 December 2012.

von Cramon-Taubadel S. (1998). Estimating asymmetric price transmission with the error correction representation: An application to the German pork market", European Review of Agricultural Economics. 25: 1-18. 



\title{
Chapter 3 Vertical Price Transmission of Milk Prices: Are Small Dairy Producers Efficiently Integrated into Markets?
}

\begin{abstract}
In recent years the dairy sector in Panama has experienced mergers and consolidations that have led to increases in industry concentration, a decrease in the number of producers, and an increase in the scale of operations. Small dairy producers have expressed concerns about the competitiveness of the dairy supply chain, arguing that price changes are not being transmitted efficiently from wholesalers to producer at the farm gate level. In this context, this chapter examines the degree of vertical price transmission between wholesalers and small dairy producers to assess the efficiency level of the dairy market chain in Panama. The findings of this research provide original and important contributions to the policy dialogue uncovering two key issues : i) an unidirectional transmission of milk prices from producers to wholesaler, and ii) that the transmission of milk prices is asymmetric depending on whether prices are increasing or decreasing.
\end{abstract}

\subsection{Introduction}

The dairy sector in Panama has undergone significant changes in recent years. For example, the dairy industry has experienced mergers and consolidations that have led to increases in industry concentration, a decrease in the number of producers, and an increase in the scale of operations. Dairy producers have expressed concerns about the competitiveness of the dairy supply chain, arguing that price changes are not being transmitted efficiently from wholesalers 
to producers. This issue has captured special attention from policy makers due to its implications on welfare distribution, hence the need for policy intervention.

Price is the main instrument by which different levels of the market are linked (Serra \& Goodwin, 2002). Thus, ensuring adequate price signals at the farm gate is fundamental to agricultural growth and productivity and consequently, to poverty reduction (Norton, 2004). A better understanding of the extent to which wholesalers' prices are being efficiently transmitted down to producers at the farm gate level is an important issue for the design of policy measures that seek not only to reduce the causes of market failure in order to increase competitiveness, but also to reduce poverty and food insecurity (Schroeder \& Hayenga, 1987).

Figure 3.1- Milk price trends at producer and wholesaler levels

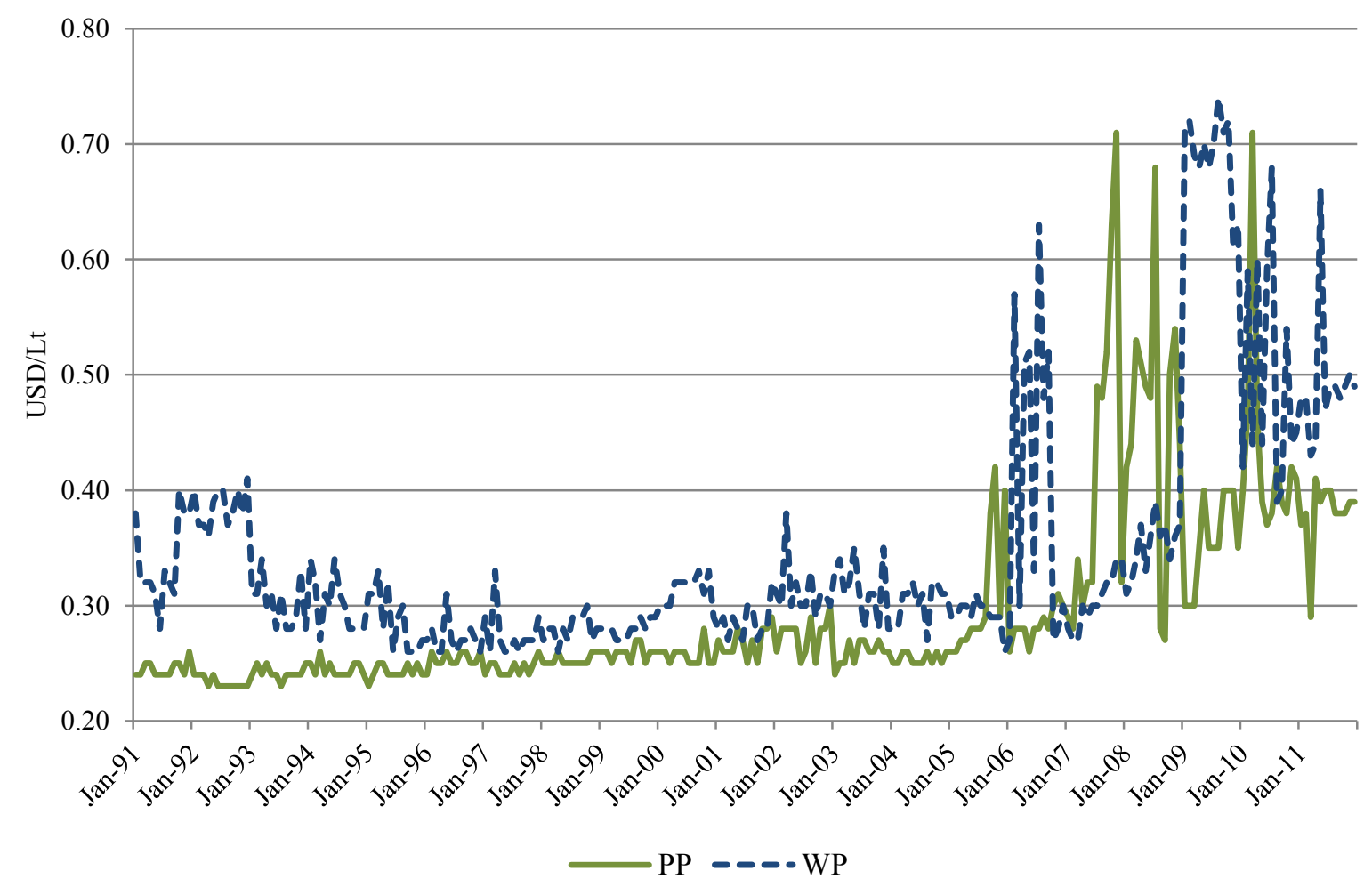

Source: Authors based on Contraloría General de la República de Panamá, 2012

In this context, this paper serves several purposes: i) to analyse if wholesalers' (WP) and producers' (PP) milk prices are cointegrated; ii) to estimate whether changes in wholesalers' milk prices are being efficiently transmitted to producers prices at the farm gate level; and iii) to assess the dynamics of the relationship between those prices (figure 3.1). 


\subsection{Structure of the milk market in Panama}

In economic terms, cattle production is one of the most important activities of the agricultural sector in Panama (accounting for 19.6\% of agricultural GDP in 2009), followed in weight by other subsectors such as tropical fruits $(18.7 \%)$, poultry $(18.5 \%)$, cereals $(16.4 \%)$, vegetables (9.8\%), pigs (6.8\%), and forestry (6.6\%). According to the 2011 Agricultural Census, Panama has about 40,000 farms with an inventory of 1.7 million head. Of this total, $48 \%$ are small farms of less than 20 hectares, which manage $13 \%$ of the national herd with an average of 11 head per farm (CGR, 2011).

Table 3.1 Cattle inventory breakdown in Panama

\begin{tabular}{ccccc}
\hline Farm Size & $\begin{array}{c}\text { Per cent age of } \\
\text { Total Farms }\end{array}$ & $\begin{array}{c}\text { Farm Size } \\
\text { (Hectares })\end{array}$ & $\begin{array}{c}\text { Per cent of National } \\
\text { Herd Under } \\
\text { Management }\end{array}$ & $\begin{array}{c}\text { Average Head } \\
\text { per Farm }\end{array}$ \\
\hline Small & $48 \%$ & $<20$ & $13 \%$ & 11 \\
Medium & $47 \%$ & $20-199$ & $55 \%$ & 45 \\
Large & $5 \%$ & $>200$ & $32 \%$ & 294 \\
\hline
\end{tabular}

Source: CGR, 2011

The largest part of the cattle production system in Panama is concentrated along the pacific coast, which has the most fertile soil in the country. The area under pasture in these provinces ranges from $72 \%$ in Los Santos, to 53\% Herrera, $47 \%$ in Chiriquí, $28 \%$ in Coclé and 26\% in Veraguas. During the last decade, Panama has observed a 13\% increase in the size of its herd, with an average growth rate of $2.1 \%$ per year, passing from 1.5 million head in 2000 to 1.7 million in 2010. This increase is particularly remarkable in the Darién province, where the number of animals has risen from 29,000 head in 2000 to 198,900 in 2010 a growth of $585 \%$ over a ten-year period.

There are three main cattle production systems in Panama: one specialized in milk, a second specialized in meat, and a third that consists of a dual-purpose system producing both milk and meat. The dual-purpose system is the most prevalent among small producers (located mainly in the lowlands, particularly in Los Santos, Herrera, and Veraguas), and is based on the crossbreeding of Bos-Inducus and Bos-Taurus breeds such as Zebu and Brown Swiss, or Zebu and Holstein. 
According to FAO (2012), small dairy producers in Panamá constitute nearly $90 \%$ of total dairy producers, and contribute with $54 \%$ of the total fluid milk production in the country. This system is characterized by the lack of dairy infrastructure, limited use of technology, poor adoption of best production practices, and low productivity with an average production of milk per day of 4.8 liters per cow. Livestock feeding problems occur in Panama during the dry season due to lack of fodder. As a consequence, the milk production system remains highly seasonal and dependent on the rainfall regime. The high production period occurs during the rainy season (between May and November) and the low production period occurs during the dry season (from December to April). Milk is classified in three main groups A, B, and C depending on its quality. Of the 168 million liters of milk produced annually in Panama, 46\% corresponds to grade A, $4 \%$ to grade B, and 50\% to grade C. Grade A is used exclusively for production of pasteurized fluid milk, while grades $\mathrm{B}$ and grade $\mathrm{C}$ are mainly used for industrial purposes (FAO, 2012).

The dairy industry encompasses six large companies, among which are NESTLÉ Panama, Industrias Lácteas S.A (Estrella Azul), Refrescos Nacionales, Productos Lácteos San Antonio S.A (PROLACSA), Sociedad de Alimentos de Primera S.A (BONLAC), and Cooperativa de Productores de Leche de Chiriquí (COOLECHE). In 2009, this group of companies purchased $88 \%$ of the national milk production. As the type of product that each industry manufactures determines the quality of milk they purchase, NESTLÉ and PROLACSA, which produce condensed milk and milk powder and manufacture a variety of cheeses, purchase mainly milk grade C. Companies such as BONLAC and Estrella Azul focus on the commercialization of pasteurized fluid milk, and mainly purchase grade A. In addition to these large companies, there are 46 small and medium dairy plants specialized in the manufacture of cheese, yogurt, and milk sweets. These companies together adsorb the remaining $12 \%$ of the national milk production, and are becoming increasingly important players in the market. This tendency is particularly relevant for small dairy producers since most of small dairy plants purchase their inputs from small dairy farmers.

According to FAO (2012), some of the factors constraining the development of the dairy sector in Panama are related to the lack of coordination between the public and private sectors in defining a national policy that would promote an increase in the competitiveness and sustainability of the sector. Such a national policy should pay close attention to strengthening the organizational capacities of small dairy producers associations, improving the public extension system (ensuring a sufficient number of well-trained technicians with specific 
knowledge about good dairy production practices, including nutrition, genetics, and pastures management) and further developing infrastructure such as roads, electricity, and marketing mechanisms in production areas.

\subsection{Vertica price transmission analysis}

Vertical price transmission analysis can be used to assess how efficiently different actors are integrated in a market. The extent and speed with which price changes are transmitted from one actor to the other in the market chain can have important policy implications for welfare distribution, competitiveness, and sustainability. In a competitive market, price shocks at one level of the market chain should be reflected by similar changes at the other levels, as market efficiency suggests a price equilibrium relationship between them (Serra \& Goodwin, 2002).

Depending on the environment in which markets operate, two prices can be related in various ways: (i) adjusting completely or partially, (ii) slowly or instantaneously and (iii) in a linear or in a non-linear manner (Ihle et al., 2009). In recent years, an extensive amount of studies have been developed to examine market linkages among farm, wholesale, and retail markets (Kinnucan \& Forker, 1987; Schroeder \& Hayenga, 1987; Goodwin \& Holt, 1999; Miller \& Hayenga, 2001; Serra \& Goodwin, 2002). The main focus of research in this area has been oriented to assessing the nature, extent of adjustment, and speed with which shocks are transmitted along the different actors in the market chain. In these studies, the rate of price response is generally measured through the lag relationship between upstream and downstream price, while the asymmetry of price response is measured as the relative response of downstream prices as upstream prices rise or fall (Miller \& Hayenga, 2001).

Most of the literature on vertical price transmission refers to non-competitive markets as the main cause of incomplete price transmission. The factors that constrain the complete and symmetric transmission of agricultural commodity prices from one market to another are classified into: : (i) market power concentration at levels beyond the farm gate; ii) different costs of adjustment when firms change the quantities and/or prices of inputs and/or outputs; iii) government intervention in the pricing of agricultural products; iv) imperfect information; v) different price elasticities at different levels of the market chain; and vi) the presence of rapidly perishable goods (Kinnucan \& Foker, 1987; Goodwin \& Holt, 1999: Meyer \& von CramonTaubadel, 2004; Serra \& Goodwin, 2002). 
Existing models that analyse vertical price transmission issues utilize several variations of a model originally introduced by Wolffram, (1971) and later modified by Houck (1977) (Acquah $\&$ Dadzie, 2010). These models are based on the regression of differentiated price data and on lagged price differences where considerations can be made for the differential effects of positive and negative lagged differences (Goodwin \& Holt, 1999). Many of these models have been criticized for being unreliable, since most of the evidence presented to support the assumption that commodity prices were cointegrated was flawed and affected by spurious regressions, non-stationary series, or inappropriate use of first differences (Ardeni, 1989). In order to deal with these econometric shortcomings, Engel \& Granger (1987) proposed a new and alternative methodological approach based on cointegration theory, which indicates that two nonstationary time-series could be long-term cointegrated if both series are integrated of the same order.

An initial attempt to use cointegration techniques in testing for asymmetric price transmission was von Cramon-Taubadel's (1998) two-step method approach based on Engel \& Granger to test for Asymmetric Price Transmission (APT) in the presence of nonstationary series using an Asymmetric Error Correction Model (AECM). In this approach, the authors proposed splitting the error correction term into positive and negative components to identify if prices are transmitted differently depending on whether they increase or decrease. Meyer and von Cramon-Taubadel (2004) pointed out several methodological issues that need to be carefully considered when conducting price transmission analysis, since they can affect results: i) the problem of multicollinearity, ii) the presence of structural breaks, iii) the issue of data frequency, iv) adjustment cost, and v) the need for a better and deeper understanding of the underlying causes of asymmetric price transmission.

\subsection{Data}

The price transmission analysis was conducted using 252 monthly observations from January 1991 to December 2011 at the wholesaler and small dairy producer level in Panama. Observations refer to nominal prices of fresh milk per liter. The source of the data is the Contraloría General de la República de Panamá. 


\subsection{Econometric methods}

As previously discussed, regressions involving nonstationary time-series will produce spurious results showing a significant relationship between variables that are not correlated. Therefore, the first step in our vertical price transmission analysis was to determine whether the timeseries contained a unit root or not. Given that series were non-stationary, and following cointegration theory, we employed the Johansen approach to test for cointegration. Then we applied the Granger Causality test to assess the possible direction of the price transmission.

Taking into account that the series were cointegrated, we followed a Two-Step Error Correction Model (ECM) to capture the short-and long-term effects of $\mathrm{X}$ on $\mathrm{Y}$, and the speed of adjustment at which a dependent variable returns to equilibrium after a change in an independent variable. Thus, as a first step we estimated equation (3.1) regressing $\mathrm{Y}$ on $\mathrm{X}$ to obtain an estimate of $\mathrm{Z}$ by taking the residuals from the regression.

$$
\begin{gathered}
y_{t}=\alpha_{0}+\alpha_{1} x_{t}+z_{t} \\
\Delta y_{t}=\alpha_{0}+\alpha_{2} \Delta x_{t-1}-\phi_{0} z_{t-1} \\
\Delta y_{t}=\alpha_{0}+\alpha_{2} \Delta x_{t-1}-\phi_{0} E C T_{t-1}+\varepsilon_{t}
\end{gathered}
$$

As a second step, we estimated equation (3.2), regressing $\Delta y_{t}$ on $\Delta x_{t-1}$ plus the equilibrium errors represented by $z_{t-1}$. This equation can be represented as a basic structure of an ECM (3.3) where $\alpha_{2}$ captures the short term effects of X on Y, and $\phi$ captures the rate at which the system adjusts to the equilibrium after a shock, in other words, the error correction term (ECT).

$$
\Delta y_{t}=\alpha_{0}+\alpha_{1} \Delta y_{t-1}+\alpha_{2} \Delta x_{t-1}-\phi_{1} E C T_{t-1}^{+}+\phi_{2} E C T_{t-1}^{-}+\varepsilon_{t}
$$

Finally, following the approach proposed by von Cramon-Taubadel and Loy (1996) to test for asymmetric price transmission, we split the error correction term (ECT) into positive and negative deviation from long-run equilibrium. As shown in equation (3.4) splitting the ECT into positive and negative components allows one to identify if the speed at which prices are transmitted differs depending on whether prices are increasing or decreasing or in other words, if price transmission is symmetric or asymmetric. 


\subsection{Results}

In order to test for the presence of unit roots, we used an Augmented Unit Root Test (ADF) for the variables PP and WP. Taking into account potential autocorrelation problems, the number of optimal lags was determined using the Akaike information criteria. The results of the unit root tests (Table 3.2) indicate that for the PP and WP variables, there is insufficient evidence to reject the null hypothesis of unit roots at the five per cent level.

Table 3.2 Unit Root Test

\begin{tabular}{ccccccc}
\hline Variable & Test & Lags & $H o: \gamma=0$ & Lags & $H o: \Delta \gamma=0$ & $\begin{array}{c}\text { t-statistics critical values } \\
\text { at } 5 \% \text { level }\end{array}$ \\
\hline PP & ADF & 8 & -3.11 & 7 & -6.98 & -3.41 \\
WP & ADF & 2 & -2.24 & 1 & -16.44 & -2.86 \\
\hline
\end{tabular}

Source: Authors

Considering that the PP and WP are nonstationary series integrated of the same order, a Johansen Trace Test was used to determine if the variables are long-run cointegrated. The results of the Johansen's Test (Table 3.3) indicate that there is strong evidence to reject the null hypothesis of non-cointegration between WP and PP, suggesting the existence of a long-run single cointegration relationship between wholesalers' and producers' prices.

Table 3.3 Johansen Trace Test

\begin{tabular}{cccccc}
\hline Variable & Lags & Ro & LR & P-Value & $\begin{array}{c}\text { t-statistics critical values at 5\% } \\
\text { level }\end{array}$ \\
\hline WP & 9 & 0 & 27.75 & 0.003 & 20.16 \\
PP & & 1 & 1.89 & 0.794 & 9.14 \\
\hline
\end{tabular}

Source: Authors

In order to assess the possible direction of price transmission, we applied a Granger Causality Test. As shown in table 3.4, we can reject the null hypothesis that producers' milk prices do not cause wholesalers' prices $(\mathrm{P}<0.05)$ but not inversely. The result of the Granger causality test shows that the direction of price transmission tends to go from producers to wholesalers. 
Table 3.4 Granger Causality Test

\begin{tabular}{lll}
\hline Null Hypothesis & F-Statistics & Prob. \\
\hline PP does not cause WP & 3.97 & 0.02 \\
WP does not cause PP & 2.81 & 0.06 \\
\hline
\end{tabular}

Source: Authors

We specified a two steps single equation error correction model (ECM) to assess the dynamics of the relationship between the different price series. The ECM allowed us to capture the shortterm effect that a shock in the independent variables has on the dependent variable and the speed at which the system will adjust to the new equilibrium after the shock. The result of the Granger causality test indicates that in the setting of an ECM, the series WP should be on the left hand side.

$$
\Delta W P_{t}=\underset{(0.548)}{0.002}-\underset{(-6.939)}{0.423^{* * * *}} \Delta W P_{t-1}-\underset{(-1.94)}{0.121} \Delta P P_{t-1}-\underset{(-2.535)}{0.091^{* * *}} E C T
$$

The output of the ECM (3.5) indicates that while the coefficient (-0.091) of the error correction term $\phi$ is significant at the $5 \%$ level $(-2.535)$, the coefficient $(-0.121)$ of the short term parameter $\beta$ is not (-1.94). This result suggests that wholesaler's and producer's prices share a long-term equilibrium relationship, that a change in producer's prices do not have a significant effect on wholesaler's prices in the next period, and that the speed at which prices tend to converge to fully correct for deviation is moderately slow. Taking into account the previous results, we constructed an Asymmetric Error Correction Model (AECM) to assess if the transmission of milk price between producers and wholesalers is symmetric or asymmetric, in other words if there are significant differences in the speed of adjustment when prices increase or decrease.

$$
\Delta W P_{t}=-\underset{(-1.15)}{0.007}-\underset{(-6.98)}{0.422^{* * * *}} \Delta W P_{t-1}-\underset{(-2.42)}{0.159^{* * *}} \Delta P P_{t-1}-\underset{(-2.36)}{0.328^{* * *}} E C T^{-}-\underset{(-1.0)}{0.045} E C T^{+}
$$

The result of the AECM (3.6) indicates that while the coefficient of the $E C T^{-}(-0.328)$ is significant at the $5 \%$ level (-2.36), the coefficient of the $E C T^{+}(-0.045)$ is not (1.0). This output reveals that the transmission of milk prices is asymmetric with respect to the speed of adjustment indicating that when producers' prices increase the speed of adjustment tend to be 
significantly faster, but when prices decrease there are not statistically significant changes in the speed of adjustment. This result contrasts with the findings of Serra and Goodwin (2002), which found that the transmission of prices is reasonably symmetric in the Spanish dairy sector. However, it is consistent with findings from Kinnucan and Forker (1987) that confirmed the presence of asymmetric vertical price transmission in the U.S. dairy sector.

Finally, the focus group discussions with producers identify that some of the factors that might be affecting the level of efficiency of the milk market are related to: the presence of a large number of poorly organized dairy producers combined with a small number of well-articulated industrial processors, leading to the low bargaining power of dairy producers; a perishable product which restricts the geographic movement of raw milk, forcing producers to sell their product through local milk collectors even if prices are higher in other markets; the fear of potential substitution by an alternative supplier if they reduce their delivery quota below a certain level; and a large proportion of fixed and specific inputs that prevent a low-cost reallocation of capital resources in the short run, in addition to cash flow constraints.

\subsection{Conclusions}

The results of the analysis have shown that a long-run single cointegration relationship exists between wholesalers' and producers' prices; that the direction of price transmission tends to go from producers to wholesalers; that a change in producer's prices do not have a significant effect on wholesaler's prices in the next period; that the speed at which prices tend to converge to fully correct for deviation is moderately slow; and that when producers' prices increase the speed of adjustment tend to be significantly faster, in other words that price transmission is asymmetric. These results have serious welfare policy implications, since asymmetric transmission of milk prices implies that small dairy producers are not benefiting from price changes as much as they would under a more competitive scenario. If market price signals are not being efficiently transmitted to producers at the farm gate, it is unlikely that small producers will adopt the necessary mechanisms to respond adequately and quickly to changes in the market structure. 


\section{References}

Acquah, H., Dadzie, S. (2010). An application of the von Cramon-Taubadel and Loy error correction models in analyzing asymmetric adjustment between retail and wholesale maize prices in Ghana. Journal of Development and Agricultural Economics 2(4): 100-106.

Ardeni, P. (1989). Does the Law of One Price Really Hold for Commodity Prices? American Journal of Agricultural Economics 71(3): 661-669

Enders, W. (2005). Applied Econometric Time-series . 2nd Edition. New York: John Wiley and Sons. Harris, R. 1995.

Engel, R., Granger, C. (1987). Co-integration and Error Correction: Representation, Estimation and Testing. Econometrica 55(2): $251-276$.

Food and Agriculture Organization of the United Nations (FAO). (2012). Situación y Desafíos del Sector Ganadero en Panamá. Documento de Trabajo. Proyecto TCP/RLA/3303: Políticas de Apoyo al Desarrollo Sostenible del Sector Ganadero en Centroamérica. Ciudad de Panamá, Julio de 2012.

FAOSTAT. (2012). Food and Agriculture Organization of the United Nations (FAO) Statistics Division. Food and Agricultural Commodity Production Database. http://faostat.fao.org/site/339/default.aspx Accessed 1 October 2012.

Goodwin, B., Holt, M. (1999). Price Transmission and Asymmetric Adjustment in the US Beef Sector. American Journal of Agricultural Economics 83(2): 302-317.

Ihle, R., von Cramon-Taubadel, S., Zorya, S. (2009). Markov-Switching Estimation of spatial Maize Price Transmission Processes Between Tanzania and Kenya. American Journal of Agricultural Economics 91(5): 1432 - 1439.

Kinnucan, H., Forker, O. (1987). Asymmetry in Farm-Retail Price Transmission for Major Dairy Products. American Journal of Agricultural Economics 69:285-292.

Norton, R. (2004). Agricultural Development Policy. Concepts and Experiences: Concepts and Experiences. Food and Agricultural Organization of the United Nations - FAO. Rome.

Meyer, J., von Cramon-Taubadel, S. (2004). Asymmetric Price Transmission: A Survey. Journal of Agricultural Economics, Blackwell Publishing 55(3): 581 - 611.

Miller, D., Hayenga, M. (2001). Price Cycles and Asymmetric Price Transmission in the U.S. Pork Market. American Journal of Agricultural Economics 83: 551-562

Contraloría General de la República de Panamá (CGRP). (2011). VII Censo Nacional Agropecuario, 2011. Resultados Finales, Ciudad de Panamá, Diciembre 28 del 2011.

Contraloría General de la Republica de Panamá (CGRP). (2012). Base de datos sobre precios de alimentos de la canasta basica nacional. Ciudad de Panamá, Octubre del 2012.

Schroeder, T., Hayenga, M. (1987). Short-Term Vertical Market Price Interrelationships for Beef and Pork. North Central Journal of Agricultural Economics 9(2): 171-190. 
Serra, T., Goodwin, B. (2002). Price Transmission and Asymmetric Adjustment in the Spanish Dairy Sector. 2002 Annual meeting, July 28-31, Long Beach, CA 19622, American Agricultural Economics Association (New Name 2008: Agricultural and Applied Economics Association).

Von Cramon-Taubadel, S. (1998). Estimating Asymmetric Price Transmission with the Error Correction Representation: An Application to the German Pork Market", Euro. Rev. Agric. Econ. 25: 1-18. 


\title{
Chapter 4 Combining Industrial Organization and Econometric Methods in Price Transmission Analysis
}

\begin{abstract}
The degree of competition and level of price transmission in food markets have important effects on the welfare level of consumers and producers. Thus, substantial attention has been paid to analysis of price transmission in food markets. Traditionally, price transmission analyses have focused on applying econometric methods to assess whether prices are cointegrated, the order of cointegration and the adjustment speed. In contrast, less attention has been devoted to the theoretical underpinnings, the structure of the market and the interpretation of results. To address this gap, this study explores how to combine industrial organization methods and time-series econometrics in price transmission analyses to inform policy choices. The study illustrates the complementarity of these methods in identifying the factors that determine the level of price transmission, assessing the price dynamics between producers and wholesalers, and linking the empirical results with theory. The study uses the Panama's milk market to illustrate this approach.
\end{abstract}

\subsection{Introduction}

The degree of competition and the level of price transmission in food markets has important effects on the welfare level of consumers and producers (Sexton and Lavoie, 2001). Recent studies (Dawe et al., 2015; Dawe and Maltsoglou, 2014) stress the importance of deeply understanding the price dynamics of food markets in explaining the welfare effects of policy measures on food security. Current trends in mergers and acquisitions, coupled with increases in industry concentration have captured the attention of policy makers regarding the 
performance of food markets and the lack of transparency in the transmission of prices (McCorriston, 2013). In Panama, articles appeared in various newspapers in 2007 suggesting that processors agreed on the price of milk paid to producers, which highlighted the lack of transparency in the milk market and motivated the national antitrust authority to open an investigation against industrial processors over the alleged use of monopolistic practices. The investigation found that four major processors exchanged information that ultimately led them to agree on the purchase price of milk paid to producers.

Substantial attention has been given to analysis of the level of price transmission in food markets during recent decades (for reviews see Meyer and von Cramon-Taubadel, 2004; Frey and Manera, 2007; Bakucs et al, 2014). Traditionally, price transmission analysis has focused on applying econometric methods to assess if prices are co-integrated, the order of cointegration and the adjustment speed. However, less attention has been devoted to the theoretical underpinnings, the understanding of the market structure, and the interpretation of results (Meyer and von Cramon-Taubadel, 2004). Goodwin and Vavra (2009), in an overview of the empirical literature addressing vertical and spatial price transmission, highlight that the results of price transmission analysis are not sufficiently informative without a deeper understanding of the market structure relevant to the commodity in question. Moreover, Miller and Hayenga (2001) note that although economists have proposed many approaches for price transmission analyses, the econometric methods often used are limited because they cannot identify plausible explanations of price behaviour under competing theories. According to Peltzman (2000), an explanation of incomplete price transmission requires a better understanding of market linkages.

Acknowledgement of these issue has stimulated recent studies (Lloyd et al. 2004; Brümmer et al., 2009; Ihle et al., 2012; Götz et al., 2013) to incorporate the use of market structure information in price transmission analyses. This study takes this approach further by exploring how to combine industrial organization (IO) and econometric research methods for price transmission analysis to inform policy choices. With this aim, this research uses a three-step approach. First, we employ IO methods to analyse the structure of the milk market. Second, we use time-series econometrics to analyse the price dynamics, particularly the marketing margin, between producers and wholesalers. Finally, we triangulate the different sources of information to gain a better understanding of the interrelations among the factors that influence the transmission of prices, linking the evidence with theory. 


\subsection{Price transmission analysis}

Price transmission analyses use different modifications of a model introduced by Granger (1981) and then extended by Engel and Granger (1987) based on cointegration theory. Cointegration theory stipulates that if the linear combination of nonstationary series is stationary, then the series are said to be cointegrated (Engel and Granger, 1987). A major aspect of cointegrated series is that their dynamics are affected by the degree of deviations from the long-run equilibrium relationship (Enders, 1998).

This implies that a close relationship exists between cointegration and error correction models (ECM), as suggested by Granger (1981). ECMs have been widely used in price transmission under the idea that a fraction of a disadjustment from one period is corrected in the next period (Engel and Granger, 1987). Studies have found that the transmission of food prices tends to be nonlinear, rather than linear (Hassouneh et al., 2012); indeed, the nonlinear transmission of prices seems to be the rule rather than the exception (Meyer and von Cramon-Taubadel, 2004). In this regard, much of the research on price transmission has focused on capturing these nonlinearities (Kinnucan et al., 1987; Serra and Goodwin, 2002; Awokuse and Wang, 2009: Bolotova et al., 2012; McLaren, 2015).

Following the concept of the non-symmetric ECM introduced by Granger and Lee (1989), von Cramon-Taubadel (1998) proposes splitting the error correction term into positive and negative components to test for asymmetries in the transmission of prices, depending on whether they increase or decrease. As indicated by Abdulai (2000), under the presence of transaction costs, movement towards equilibrium does not always occur. Awokuse and Wang (2009) highlight that studies that ignore threshold effects in the transmission of prices may be misleading. To overcome this problem, studies have applied different modifications of threshold vector error correction models (TVECM) as a way to incorporate the effects of transaction costs in price transmission analyses, allowing error correction specifications to adequately capture nonlinear and threshold-type price adjustments (Goodwin and Holt, 1999; Serra and Goodwin, 2002; Balcome et al., 2007 Bekkerman et al., 2013).

In recent years, regime-dependent vector error correction models (RVECMs) have received notable attention in the literature. According to Ihle et al. (2011) the parameters governing price interdependence might not be constant, indicating that if this characteristic is disregarded, the model will be misspecified. Hassouneh et al. (2010) use a RVECM to assess the impact of 
bovine spongiform encephalopathy (BSE) outbreaks in the Spanish dairy sector and show that the BSE crises affected producer and retailer prices differently. Busse et al. (2012) employ a Markov-switching vector error correction model (MS-VECM) to analyse changes in the relationship between diesel and biodiesel prices due to changes in market conditions. Amikuzuno and von Cramon-Taubadel (2012) apply a modification of the VECM with seasonally regime-dependent adjustment parameters, showing that not accounting for seasonality can lead to compound estimates of the parameters that indicate price transmission behaviour but overlook seasonal differences in the price dynamics.

\subsection{Determinants of price transmission}

A fundamental step in IO research is the need to develop preliminary theoretical propositions that make it possible to link the empirical results with theory and draw inferences concerning causal relationships among the variables under investigation. Each proposition should focus on particular factors to provide relevant evidence during the research study (e.g., Holst and von Cramon-Taubadel, 2014). Lloyd et al. (2004), in an analysis of price transmission in imperfectly competitive vertical markets, identify the following proposition: "Proposition 1: Market power at the retail stage, either in form of oligopoly or oligopsony power, will result in a differential impact on farm level prices than on retail prices following an exogenous shift in the demand function. With oligopoly power, price transmission from retail to farm prices will increase; with oligopsony power, price transmission will decrease" (p.6).

In food markets, the level of price transmission is related to the shapes of the supply and demand curves (Kim and Ward, 2013). Thus, the structure of the market matters in explaining the response of prices on one level to shocks in another (Carlton and Perloff, 2004). Standard economic theory suggest that the elasticity of price transmission will be equal to one in a competitive market, which implies that price changes will be transmitted completely from processors to farmers after a shock. In an oligopolistic market, the elasticity of price transmission will be higher than one, meaning that the margin between processors and farm prices will expand (contract) after a negative (positive) demand shock. In an oligopsony market, the elasticity of price transmission will be lower than one, the reason being that the margin between processors and farm prices will contract (expand) after a negative (positive) shock (Lloyd et al. 2004). 
The ability of the market structure to transmit price signals up and down through the system is a reflection of market performance (Kim and Ward, 2013). Although in price transmission analysis, perfect competition has often been understood as having an elasticity that equals one, Kinnucan and Zhang (2015) show that this definition is inconsistent and that a competitive market does not require the elasticity of price transmission to be one. Indeed, Weldegebriel (2004) shows that market power does not necessarily lead to incomplete price transmission. Moreover, Peltzman (2000) argues that incomplete price transmission may be a feature of competitive, as well as oligopolistic, market structures.

Bakucs et al. (2014) find that incomplete price transmission is likely to occur in sectors with more divided farm structures, higher governmental assistance and more restrictive norms on price controls. According to Bolotova and Novakovic (2012) price control rules facilitate cooperative conduct of actors acting in an oligopolistic market environment. Meyer and von Cramon-Taubadel (2004) highlight that if firms are engaged in unspoken collusion, actors will tend to adjust input price increases faster than decreases in order to signal to their competitors that collusion will be maintained. Serra and Goodwin (2002) identify that retail prices adjust to farm level shocks, but that farm prices respond modestly to retail price shocks, explaining that the lack of producers' organization limit their power to negotiate prices.

Several authors (Abdulai, 2000; Conforti, 2004; Frey and Manera, 2007; Sanogo and Amadou, 2010) find that if transaction costs are extremely high, often related to poor infrastructure, particularly roads and marketing facilities, changes in prices will be only partially transmitted or not transmitted at all. Other studies argue that incomplete price transmission is also related to menu costs, frequently called sticky prices, which are often fixed costs, transaction costs and adjustment costs associated with increasing or decreasing output prices (Kinnucan and Forker, 1987; Goodwin and Holt, 1999).

Policy measures such as import tariffs can also hinder the complete transmission of market signals from international to domestic markets, leading to incomplete price adjustments (Martin and Anderson, 2012). A tariff import quota reduces the opportunities for spatial arbitrage, constraining the transmission of prices from international to domestic markets. Exchange rate changes can retard the transmission of prices, mitigating internal trade price changes (Baquedano and Liefert, 2014). Intervention mechanisms can also lead to a partial comovement of international and domestic prices, where international price changes will be 
transmitted more or less complete to domestic prices depending on whether they are above or below certain price levels (Rapsomanikis et al., 2003).

Economic theory suggests that the degree of price transmission can be explained by the structure of the respective market. The empirical evidence reveals that while in some cases, markets are well described by this theory, in others, they are not. The determinants of price transmission differ among markets, with the degree of concentration being an important factor, but aspects such as menu costs, transaction cost, and trade-policy mechanisms are also involved.

IO research methods appear to be a valuable complementary tool for understanding the underlying factors that explain the level of price transmission in food markets, interpreting these findings and linking the evidence with theory (Armstrong et al., 2007; Carlton and Perloff, 2004). In fact, IO research methods might be of the most benefit when the focus of the research is on explaining the "how" or "why". In this regard, a major strength of IO research is its ability to use multiple sources of evidence, including documents, media searches, semistructured interviews, focus group discussions and participant observations (Yin, 2013).

\subsection{Methodology}

A fundamental observation made in the empirical literature is that the results derived from price transmission analysis are not sufficiently informative without a deeper understanding of the market structure (Goodwin and Vavra, 2009). This study address this issues by exploring how to combine IO and econometric research methods in price transmission analysis. With this aim, this research uses a three-step approach (figure 4.1).

First, we employ IO methods to analyse the structure of the milk market. Second, we use timeseries econometrics to analyse the price dynamics between producers and wholesalers. Third, we triangulate the different sources of information, bring together the evidence derived from both analysis, to better understand the interrelations among the factors that influence the transmission of prices and link the empirical results with the theoretical propositions. 
Time-series econometric methods are used to analyse the price dynamics between producers and wholesalers. A major factor in price analysis is to determine if the series are stationary or nonstationary. A standard ADF is use to test for unit roots in both variables while also considering the potential presence of structural breaks in the series (Perron, 1989; Saikkonen and Lukepohl, 2002; Wang and Tomek, 2007). The unit root test with structural breaks propose by Saikkonen and Lutkepohl (2002) is also employed.

A fundamental assumption of VECMs is that the parameters of the model remain constant throughout the sample period. However, the results of IO analysis suggest that a structural change in the milk market might have occurred around January 2006. Thus, we test for structural stability using a break point (BP) Chow test (Candelon and Lütkepohl, 2001). Given that both series are nonstationary, we employ the Johansen approach to test for cointegration (Johansen, 1991). Then, we apply a VECM to assess the price dynamics between the series. Considering that our specific interest is to assess the effect of the structural policy change on the price spread relationship between producers and wholesalers we specified a VECM (4.1) where a policy dummy variable influences the constant term of the cointegration relationship (Esposti and Listorti, 2013).

$$
\Delta l p_{t}=\alpha\left[\beta l x_{t-1}+\mu C_{t-1}+\delta D_{c t-1}\right]+\sum_{i=1}^{p-1} \Gamma \Delta l p_{t-i}+\varepsilon_{t}
$$

The VECM is specify as (4.1), where $p$ is a vector of producer and wholesaler prices in logarithms, $\alpha$ is the loading matrix containing the speed at which the variables adjust to deviations from long-run (LR) equilibrium; $\beta$ represents the cointegrating matrix quantifying the prices' long-term equilibrium relationship; $\mathrm{C}$ is a constant term that captures all the elements contributing to the price spread associated with the marketing margin between producers and wholesalers; $D_{c}$ denotes a structural change dummy variable that takes the value of zero from January 1991 to December 2005 and one between January 2006 and December $2013 ; \Gamma, i=1, \ldots, p-1$, contains the matrices of short-term parameters to be estimated. Finally, we triangulate the different sources of information, bringing together the evidence derived from both analysis, in order to improve our understanding of the aspects that affect the complete transmission of prices, and link the empirical results with the theoretical propositions. 


\subsection{Data gathering}

The IO analysis was conducted using different sources of information, including a competitiveness analysis of the dairy sector, value chain studies, official government reports and major national newspapers. Semi-structured interviews with key public and private actors related to the dairy chain included retailers (2), milk processors (3) and milk producers (10). Focus group discussions (2) occurred with key stakeholders involved in the milk supply chain, including the Panamanian Livestock Dairy Institute (IPAGAL) and the Livestock National Producers Association (ANAGAN). The time-series analysis was conducted using 252 monthly observations of fresh whole milk prices over the period of 1991 (1) to 2013 (12) provided by the Agricultural Information System of the Contraloria General de la República de Panamá. The data are related to milk prices at the producer level and the wholesale level in Panama.

\subsection{Results}

\subsubsection{Industrial organization (IO) analysis}

Panama produces around 206 million kg of fluid milk equivalent (FME), imports 112 million FME, and exports 22 million FME. Thus, total availability of milk is about 296 million FME. The dependency ratio is 38 per cent and the average consumption per capita is 77 litres per year. As shown in Figure 4.2, there are about 6630 milk producers, with 6 per cent producing Grade A milk, 4 per cent producing Grade B milk, and 90 per cent producing Grade C milk. From the 206 million $\mathrm{kg}$ the country produced in 2013, 46 per cent was Grade A, 6 per cent was Grade B and 48 per cent was Grade C. Grades A and B are used to supply the domestic market with fresh milk, while Grade $\mathrm{C}$ is used mainly for industrial purposes, the elaboration of traditional cheese and self-consumption at the farm level. From all the domestic supply, 75 per cent goes to the industry, 15 per cent to traditional processors and the remaining 10 per cent is destined for household consumption. 
Figure 4.2 Milk market structure

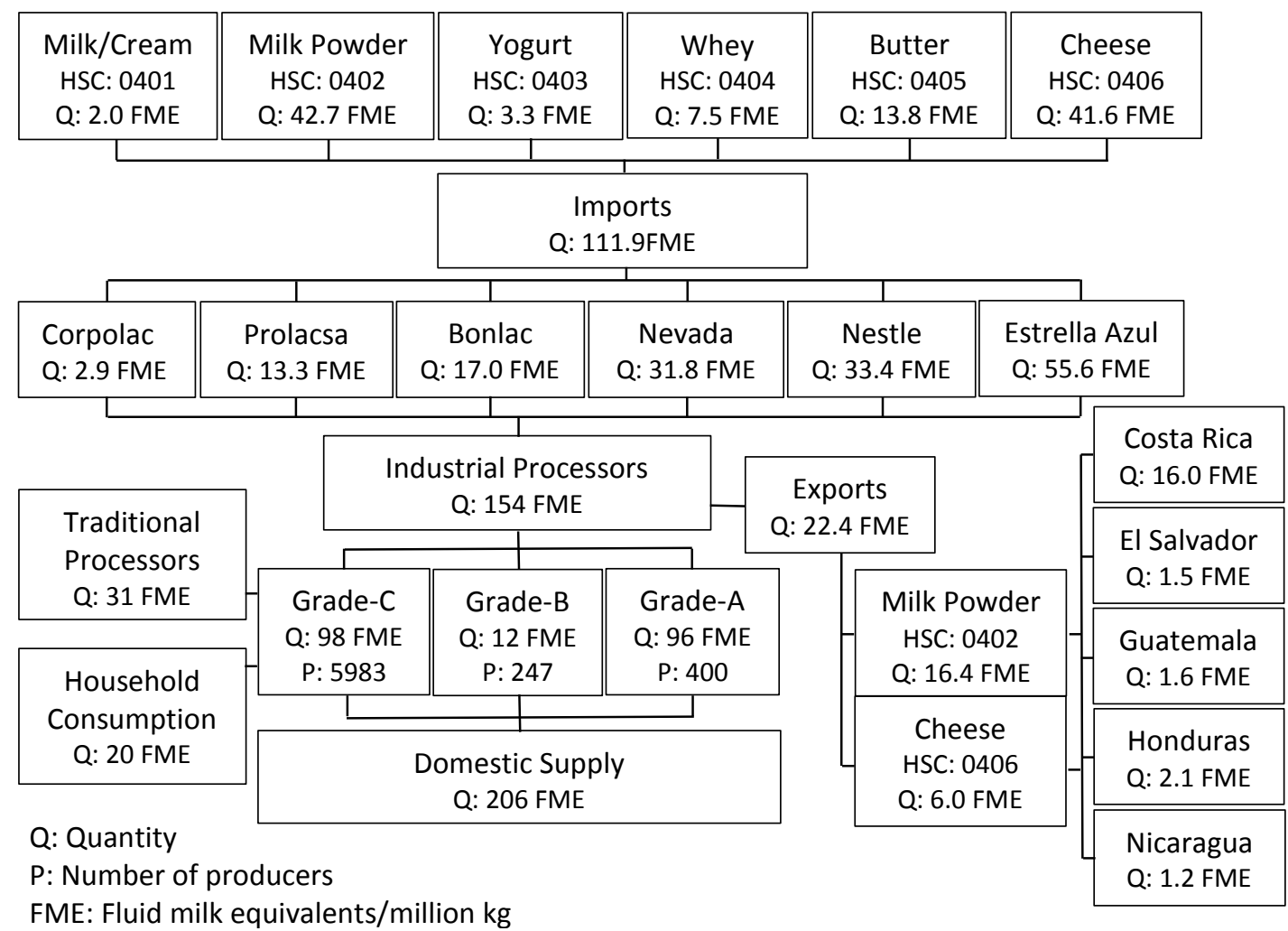

Source: Authors based on data from the Ministerio de Desarrollo Agropecaurio (MIDA), 2010; Contraloría General de la República de Panamá (CGRP), 2011); Instituto nacional de estadística y censo de Panama (INEC), 2014.

There are six major milk processing companies in the country. In 2013, the three biggest of these processors absorbed nearly 80 percent of the supply oriented to the industrial market. During the last ten years the dairy processing sector has experienced mergers and consolidations; for example, Coca-Cola FEMSA (Fomento Económico Mexicano S.A) from Mexico acquired Estrella Azul; the cooperative Dos Pinos from Costa Rica acquired Nevada; and the company Casa Luker from Colombia acquired Bonlac. These recent developments have led to changes in the structure of the market, not only due to the increase in the size of operations, but also because of the type of products they demand.

Panama has traditionally been a net importer of dairy products. In 2013, the country imported 112 million $\mathrm{kg}$ of FME units with a value of US\$104 million. From total imports, in terms of value, cheese accounted for 53 per cent, milk powder for 26 per cent, butter for 8 per cent, whey for 6 per cent, yogurt for 5 per cent and fluid milk and cream for 3 per cent. The export of dairy products from Panama has been relatively low; in 2013 the country exported about 22 
million kg of FME units with a value of US\$11.5 million; of this total 73 per cent was milk powder and 27 per cent was cheese. Due to tariff preferences obtained under the free trade agreement between Central America and Panama, dairy exports went mainly to Costa Rica, El Salvador, Guatemala, Honduras and Nicaragua.

The visual analysis of the price series in Figure 4.3 shows that between 1991 and 2005 producer (PP) and wholesaler (WP) milk prices were relatively stable moving around 25 cents per litre. However, the graph also reveals that after 2006, milk prices increased and became more volatile indicating that a major change in the structure of the market might have occurred during this period.

Figure 4.3 Producer and wholesaler milk prices

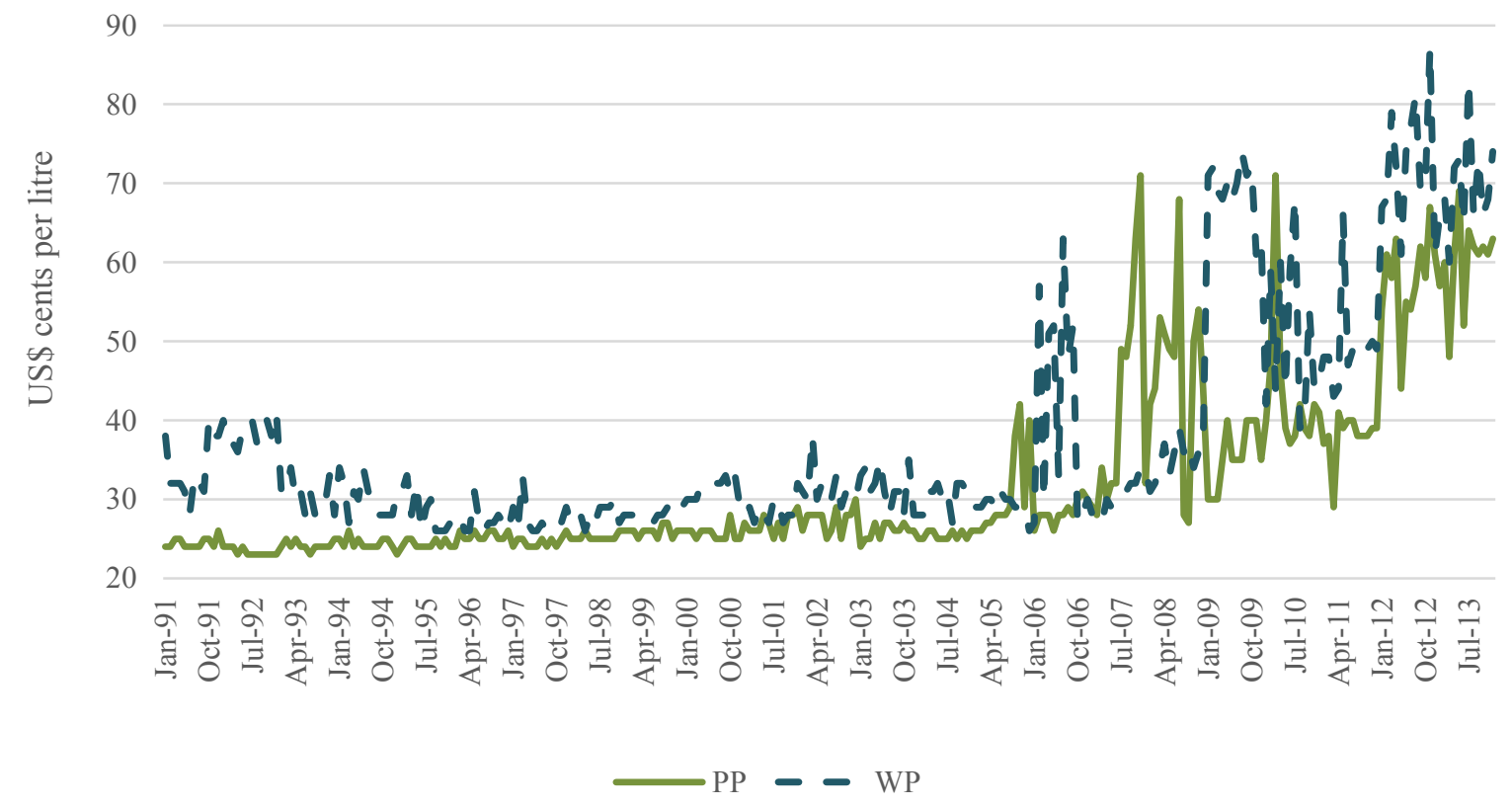

Source: Authors based on price data from the Contraloria General de la República de Panamá CGRP), 2014.

The results of the media search (Table 4.2) reveal that around 2006 dairy producers and milk industrial processors engaged in a price discussion for the alleged use of monopolistic practices by industrial processors. In an article published on January 2006, producers argue that while processors increased dairy prices for consumers by between 1 and 10 cents, dairy prices paid to producers remained constant at 20 cents per litre (Berrocal, 2006). Thus, producers requested industrial processors to increase the price of fluid milk paid at the farm gate level (Guerra, 2006). 
Producers accused processors of the use of monopolistic practices, requesting the National Authority for Consumer Protection (ACODECO) to verify that there was not a price agreement among economic actors (Guerra, 2006). Subsequently, producers threatened processors with strike action if prices per litre of milk were not increased by 9 cents per litre (Torres, 2007). Industrial processors did not meet the producer request (Tapia, 2007) offering a price rise of 3 cents, instead. Producers accepted the offer but indicated that they were exploring other actions to ensure more competitive prices (Tapia, 2007). In March 2008, ACODECO sued four major industrial processors for the presumed use of monopolistic practices to fix milk prices paid to producers (De Gracia, 2008).

Table 4.2 Media search timeline results

\begin{tabular}{clc}
\hline Timeline & \multicolumn{1}{c}{ News headlines } & Newspaper \\
\hline 12 Jan. 2006 & $\begin{array}{l}\text { While major dairy processors in Panama increased milk } \\
\text { prices at the consumer level, producer prices remained } \\
\text { constant. }\end{array}$ & La Prensa \\
12 Oct. 2006 & $\begin{array}{l}\text { Dairy producers requested industrial processors to adjust } \\
\text { the prices paid for raw milk at the farm gate level. }\end{array}$ & La Prensa \\
22 Nov. 2006 & $\begin{array}{l}\text { Producers accused industrial processors of acting as a } \\
\text { monopoly, fixing the price per litre of raw milk paid to } \\
\text { producers. }\end{array}$ & La Prensa \\
& $\begin{array}{l}\text { Producers threatened industrial processors with strike } \\
\text { action if raw milk prices were not adjusted. }\end{array}$ & La Prensa \\
7 Jun. 2007 2007 & $\begin{array}{l}\text { Producers accepted the price adjustment offered by } \\
\text { industrial processors, but pointed out that they will explore } \\
\text { other actions to ensure more competitive prices. }\end{array}$ & La Prensa \\
& $\begin{array}{l}\text { Four major dairy processors were sued for the alleged use } \\
\text { of monopolistic practices. }\end{array}$ & $\begin{array}{l}\text { Panamá } \\
\text { América }\end{array}$ \\
\hline
\end{tabular}

Source: Authors

The semi-structured interviews highlighted that articles that appeared in various newspapers during 2007 motivated ACODECO to open an investigation against four industrial milk processors for presumed collusion. The investigated processors were found guilty of having incurred in monopolistic practices. The evidence revealed that they had exchanged information that ultimately led to impose the purchase price of raw milk paid to dairy producers. As a result, a fine of hundred thousand dollars was defined for each of the companies involved and an audit process established. The interviews also revealed that while the fear of being sued for collusion has discouraged the use of absolute monopolistic practices, the lack of an antitrust 
legislation to address violations against competitive market behaviour has resulted in the use of relative monopolistic practices such as the establishment of exclusivity agreements or the use of boycotts to limit the capacity of new competitors to enter markets, both of which are more difficult to investigate and monitor.

In the focus group discussions, dairy producers pointed out that in Panama milk prices regularly increase during the dry season between January and May, and decrease during the rainy season between June and December. Producers also expressed their worries about the performance of the milk sector, arguing that price signals were not being transmitted efficiently along the supply chain. They identified that some of the factors that might be affecting the level of efficiency of the milk market are related to:

- The presence of a large number of poorly organized dairy producers combined with a small number of well-articulated industrial processors, leading to the low bargaining power of dairy producers;

- A perishable product which restricts the geographic movement of raw milk, forcing producers to sell their product through local milk collectors even if prices are higher in other markets;

- The fear of potential substitution by an alternative supplier if they reduce their delivery quota below a certain level;

- A large proportion of fixed and specific inputs that prevent a low-cost reallocation of capital resources in the short run, in addition to cash flow constraints.

The semi-structured interviews with industrial processors revealed that in Panama industrial milk processors demand fluid milk grade $\mathrm{C}$ as input for the production of ice cream and butter. The price paid to dairy producers takes into account the grade level of the product, the international price of milk powder and the supply production season. Thus, prices go slightly up or down depending on whether milk is grade $\mathrm{A}, \mathrm{B}$ or $\mathrm{C}$, whether the international price is above or below domestic price, and whether it is the dry or the rainy season. Most processors manage between two and three months of milk powder stock inventories that allow them to smooth the transmission of the prices both to producers and retailers. Stock inventories are 
usually lower during the dry season and higher during the rainy season. Thus, processors pay slightly higher prices to producers during the dry season.

\subsubsection{Time-series econometric analysis}

A standard ADF is use to test for unit roots in both variables; however, considering the potential presence of structural breaks in the series the unit root test with structural breaks (URSB) proposed by Saikkonen and Lutkepohl (2002) is also employed. Two specifications are consider for the ADF test; one includes only an intercept and the other, a trend and intercept. As to the URSB test the specification includes a shift, or a shift and a trend. The optimal number of lags are selected using the Schwarz criterion. As reported in Table 4.3, the results of the ADF and the URSB test indicate that there is insufficient evidence to reject the null hypothesis of nonstationarity at the five per cent level, confirming the presence of unit roots in both producer and wholesaler price series.

Table 4.3 Unit root tests

\begin{tabular}{ccccccc}
\hline Test & Variable & Break & Lags & $H o: \gamma=0$ & $H o: \Delta \gamma=0$ & $\begin{array}{c}\text { t-statistics critical } \\
\text { values at } 5 \%\end{array}$ \\
\hline ADF & LWP & - & 2 & -1.26 & -9.27 & -2.86 \\
& LPP & - & 3 & -0.91 & -6.38 & -2.86 \\
ADF & LWP & - & 2 & -2.54 & -8.62 & -3.41 \\
Intercept/trend & LPP & - & 3 & -3.10 & -4.72 & -3.41 \\
URSB & LWP & $2006 \mathrm{M} 2$ & 2 & -2.54 & -10.21 & -2.88 \\
shift & LPP & $2006 \mathrm{M} 1$ & 3 & -0.16 & -6.93 & -2.88 \\
$\begin{array}{c}\text { URSB } \\
\text { shift/trend }\end{array}$ & LWP & $2006 \mathrm{M} 2$ & 2 & -2.68 & -10.22 & -3.03 \\
& LPP & $2007 \mathrm{M} 12$ & 3 & -2.33 & -7.00 & -3.03 \\
\hline
\end{tabular}

Source: Authors

The previous unit roots test indicated that both series are nonstationary and the results of the media search suggested the potential presence of a structural break. A Johansen cointegration test with and without structural breaks is employ to investigate the number of cointegration relations between the series. The results of both tests presented in Table 4.4, highlight the existence of a long-run cointegration relationship between the series, indicating that wholesaler and producer variables are cointegrated. 
Table 4.4 Cointegration tests

\begin{tabular}{cccccccc}
\hline Test & Variable & Break & Lags & Ro & LR & P-value & $\begin{array}{c}\text { t-statistics critical } \\
\text { values at 5\% }\end{array}$ \\
\hline Johansen & LWP & & & 0 & 22.71 & 0.020 & 20.16 \\
& LPP & & 3 & 1 & 1.26 & 0.900 & 9.14 \\
Johansen with & LWP & 2006 & & 0 & 29.32 & 0.008 & 24.76 \\
breaks & LPP & M1 & 3 & 1 & 8.66 & 0.220 & 12.73 \\
\hline
\end{tabular}

Source: Authors

Taking into account the structural market change highlighted by the media search, the next step in the analysis involved checking the potential presence of a structural break in the series during the sample period. A BP Chow test was employed to check the parameters' constancy throughout the sample. The BP Chow tests and their respective bootstrap p-values are reported in Table 4.5. The BP Chow tests confirm the presence of a structural break in the model around January 2006.

Table 4.5 Chow tests for structural break

\begin{tabular}{ccccc}
\hline Break date & Test & Test value & $\begin{array}{c}\text { Bootstrapped } \\
\text { p-value }\end{array}$ & $\begin{array}{c}\text { Asymptotic } \text { Chi }^{2} \\
\text { p-value }\end{array}$ \\
\hline \multirow{2}{*}{$2006 \mathrm{M} 1$} & BP Chow test & 310.8673 & 0.00 & 0.00 \\
& Sample split Chow test & 13.3935 & 0.09 & 0.09 \\
\hline
\end{tabular}

Note: Bootstrap p-values based on 100 replications; sample period 1991 M3 to 2013 M12.

To assess the price dynamics between producers and wholesalers a VECM is estimated (equation 4.1). The model is built taking into account the previous results from the IO analysis which highlighted that a major structural change might have occurred in the milk market around January 2006. Thus the VECM is fitted incorporating into the cointegration matrix a constant term to capture the price spread level between producers and wholesalers, a policy change dummy variable to capture the structural change in the market.

The results of the VECM model (Table 4.6) indicate that a change in wholesale prices does not have an effect on producer prices in the short run. However, the long-run coefficient shows that a change of 1 per cent in the wholesaler price leads to a change of 0.45 per cent in producer's price in the long-run. The loading coefficient highlights that producer and wholesaler prices adjusted to disequilibrium at an average rate of 23 and 16 per cent per month respectively. 
Table 4.6 VECM Parameter Estimates

\begin{tabular}{lcc}
\hline Long-run relationship & $\hat{\beta}_{2}$ & $-0.45^{* * *}$ \\
& & $(0.13)$ \\
PP speed of adjustment & $\hat{\alpha}_{1}$ & $-0.23^{* * *}$ \\
& & $(0.04)$ \\
WP speed of adjustment & $\hat{\alpha}_{2}$ & $0.16^{* * *}$ \\
& & $(0.05)$ \\
Price spread & $\hat{\mu}$ & $-1.71^{* * *}$ \\
& & $(0.44)$ \\
Structural change dummy & $\hat{\delta}$ & $-0.30^{* * *}$ \\
& & $(0.08)$ \\
\hline
\end{tabular}

Numbers in parenthesis are standard errors. $* * *$ denote statistical significance at the 1 per cent level; ** denote statistical significance at the 5 per cent level; * denote statistical significance at the 10 per cent level.

Given that the deterministic variables, namely, the constant and the policy change dummy variable, are in logs, in order to interpret them we took the anti-log of those values. In this regard, the exponential value of the constant (-1.71) indicate that the price spread (marketing margin) between wholesaler and producer prices is approximately 18 per cent of the producer's price. Furthermore, the exponential value of the policy change dummy $(-0.30)$ indicates that this price spread was reduced to 13 per cent after the policy change.

\subsubsection{Methodological Triangulation}

The results derived from each methodology, the industrial organization and time-series econometrics, are combined in order to deeper understand how the structure of markets and behaviour of agents are affecting the level of PT in the milk market (Table 4.7). The results of the market structure analysis confirm the first proposition, highlighting that in Panama the milk market is characterized by an oligopsonistic structure constituted by six major processors and more than 6000 producers.

The results of the VECM long-term parameter confirm our second proposition, indicating that in the long-run a change of 1 per cent in the wholesale price leads to a change of 0.45 per cent in the producer's price. The results of the semi-structured interviews with the national antitrust authority corroborate our third proposition, highlighting that four processors where found guilty of having incurred in collusion practices to fix the price of milk paid to producers. The VECM policy change dummy variable confirm our four proposition, showing that after 
antitrust regulations were imposed the price spread between wholesalers and producers decreased from 18 per cent to 13 per cent.

Table 4.7 Methodological Triangulation

\begin{tabular}{lcll}
\hline \multicolumn{1}{c}{ Proposition } & Method & \multicolumn{1}{c}{ Evidence } \\
\hline $\begin{array}{l}\text { 1. } \begin{array}{l}\text { The market structure is characterized } \\
\text { by oligopsonistic competition }\end{array} \\
\begin{array}{l}\text { 2. Oligopsonistic power dampens the } \\
\text { degree of PT }\end{array}\end{array}$ & VECM & $\begin{array}{l}\text { Four major processors absorb } 90 \% \text { of } \\
\text { domestic milk supply }\end{array}$ \\
A change of 1\% in WP prices leads to \\
a change of 0.45\% in PP. \\
$\begin{array}{l}\text { Incomplete level of PT is associated } \\
\text { with the exertion of market power. }\end{array}$ & IO & $\begin{array}{l}\text { ACODECO found four processors } \\
\text { guilty of collusion. }\end{array}$ \\
$\begin{array}{l}\text { 4. Price spread narrows when markets } \\
\text { become more competitive. }\end{array}$ & VECM & $\begin{array}{l}\text { After antitrust regulations were } \\
\text { enforced the price spread decreased } \\
\text { from 18\% to 13\%. }\end{array}$ \\
\hline
\end{tabular}

Finally, the results of the semi-structured interviews and focus group discussions corroborate our four propositions, highlighting that the combination of a high level of market concentration at the industry level with an inelastic price supply function at the producer level has allowed market power to emerge and affect the level of price transmission.

\subsection{Conclusions}

This study explores how to combine the use of industrial organization and econometric methods for price transmission analysis. With this aim, the research uses a three-step approach. First, we employ industrial organization methods to analyse the structure of the milk market; second, we use a time-series econometric methods to assess the price dynamics, in particular the marketing margin, between producers and wholesalers, and finally, we triangulate the different methods to better understand the interrelations among the factors that influence the transmission of prices, and link the evidence with the theory. Based on the literature review the analytical framework is guided by the following four propositions: (1) the milk market structure is characterized by oligopsonistic competition; (2) oligopsonistic power dampens the degree of price transmission; (3) incomplete price transmission is associated with market power; (4) the price spread narrows when markets become more competitive. 
The results of the VECM long-term parameter confirm our second proposition, indicating that in the long-run a change of 1 per cent in the wholesale price leads to a change of 0.45 per cent in the producer's price. The results of the semi-structured interviews with the national antitrust authority corroborate our third proposition, highlighting that four processors where found guilty of having incurred in collusion practices to fix the price of milk paid to producers. The VECM policy change dummy variable confirm our four proposition, showing that after antitrust regulations were imposed the price spread between wholesalers and producers decreased from 18 per cent to 13 per cent. Finally, the results of the semi-structured interviews and focus group discussions corroborate our four propositions, highlighting that the combination of a high level of market concentration at the industry level with an inelastic price supply function at the producer level has allowed market power to emerge and affect the level of price transmission.

A major strength of this approach is its ability to use multiple sources of evidence including documents, media searches, semi-structured interviews, focus group discussions and econometric analysis to better understand the structure of the market and draw inferences concerning price dynamics. The main challenges identified was the difficulty of generalize the results obtained from focus group discussions and the semi-structured interviews. Nevertheless, the process also revealed that results could be generalized to theoretical propositions. The study has illustrated the complementarity of these methods to better understand the findings, to corroborate theoretical propositions and to advance theoretical concepts thereby adding to existing theoretical insights on how these factors might be interrelated. 


\section{References}

Abdulai, A. 2000. Spatial price transmission and asymmetry in the Ghanaian maize market. Journal of Development Economics, 63(2): 327-349

Amikuzuno, J. \& von Cramon-Taubadel, S. 2012. Seasonal variation in price transmission between tomato markets in Ghana. Journal of African Economies, 21(4): 669-686.

Armstrong, M. \& Porter, R.H., eds. 2007. Handbook of industrial organization (Vol. 3). Elsevier

Awokuse, T. \& Wang, X. 2009. Threshold effects and asymmetric price adjustments in U.S. dairy markets. Canadian Journal of Agricultural Economics, 57(2): 269-286.

Bakucs, Z., Fałkowski, J. \& Fertő, I. 2014. Does market structure influence price transmission in the agro-food sector? A meta-analysis perspective. Journal of Agricultural Economics, 65: $1-25$.

Balcome, K., Bailey, A. \& Brooks, J. 2007. Threshold effects in price transmission: the case of Brazilian wheat, maize, and soya prices. American Journal of Agricultural Economics, 89(2): 308-323.

Baquedano, F. G., \& Liefert, W. M. 2014. Market integration and price transmission in consumer markets of developing countries. Food Policy, 44: 103-114.

Berrocal, R. 2006. Nestlé aumenta los precios de sus productos lácteos. La Prensa. (available at http://impresa.prensa.com/economia/Nestle-aumenta-precios-productoslacteos_0_1657334426.html).

Bekkerman, A., Goodwin, B. \& Piggott, N. 2013. A variable threshold band approach to measuring market linkages. Applied Economics, 45(19): 2705-2714.

Bolotova, Y.V. \& Novakovic, A.M. 2012. The impact of the New York state milk price gouging law on the price transmission process and supermarket pricing strategies in the fluid whole milk market. Agribusiness, 28(4): 377-399.

Brümmer, B., von Cramon-Taubadel, S. \& Zorya, S. 2009. The impact of market and policy instability on price transmission between wheat and flour in Ukraine. European Journal of Agricultural Economics, 36(2): 203-230.

Busse, S., Brümmer, B. \& Ihle, R. 2012. Price formation in the German biodiesel supply chain: a Markov-switching vector error-correction modeling approach. Agricultural Economics, 43(5): 545-560.

Candelon, B., \& Lütkepohl, H. 2001. On the reliability of Chow-type tests for parameter constancy in multivariate dynamic models. Economics Letters, 73(2): 155-160.

Carlton, D.W. \& Perloff, J.M. 2004. Modern industrial organization. 4th edition. Pearson.

CGRP (Contraloría General de la República de Panamá). 2011. VII Censo Nacional Agropecuario, 2011. Resultados finales, Ciudad de Panamá. 
CGRP. 2014. Base de datos sobre precios de alimentos de la canasta básica nacional. Ciudad de Panamá.

Conforti, P. 2004. Price transmission in selected agricultural markets. Working Paper No. 7, FAO Commodity and Trade Policy Research.

De Gracia, M. 2008. Demandan a empresas lácteas debido a supuesto monopolio. La Prensa. (available at http://www.panamaamerica.com.pa/content/demandan-empresas1\%C3\%A1cteas-debido-supuesto-monopolio).

Dawe, D., Morales-Opazo, C., Balie, J., \& Pierre, G. (2015). How much have domestic food prices increased in the new era of higher food prices?. Global Food Security, 5, 1-10.

Dawe, D., \& Maltsoglou, I. 2014. Marketing margins and the welfare analysis of food price shocks. Food Policy, 46, 50-55.

Engel, R. \& Granger, C. 1987. Cointegration and error correction: representation, estimation, and testing. Econometrica, 55(2): 251-276.

Enders, W. 1998 Applied econometric time-series . John Wiley \& Sons, Inc.

Esposti, R. \& Listorti, G. 2013. Agricultural price transmission across space and commodities during price bubbles. Agricultural Economics, 44(1):125-139.

Frey, G. \& Manera, M. 2007. Econometric models of asymmetric price transmission. Journal of Economic Surveys, 21(2): 349-415.

Goodwin, B.K. \& Holt, M.T. 1999. Price transmission and asymmetric adjustment in the US beef sector. American Journal of Agricultural Economics, 81(3): 630-637

Goodwin, B.K. \& Vavra, P. 2009. What can we learn from spatial and vertical price transmission studies?. Empirical examples from U.S. meat markets. Paper prepared for the Courant Research Centre \Poverty, Equity and Growth" Inaugural Conference at the University of Gottingen, Germany.

Götz, L., Glauben, T., \& Brümmer, B. 2013. Wheat export restrictions and domestic market effects in Russia and Ukraine during the food crisis. Food Policy 38: 214-226.

Granger, C. 1981. Some properties of time-series data and their use in econometric model specification. Journal of Econometrics, 16(1): 121-130

Granger, C. \& Lee, T. 1989. Investigation of production, sales and inventory relationships using multicointegration and non-symmetric error correction models. Journal of Applied Econometrics, 4: 145-159

Guerra, D. 2006. Lecheros denuncian monopolio de precios. La Prensa. 22 November (available at http://impresa.prensa.com/economia/Lecheros-denuncian-monopolioprecios_0_1887561357.html).

Guerra, D. 2006. Lecheros inician negociación con industriales. La Prensa, 11 September (available at http://impresa.prensa.com/economia/Lecheros-inician-negociacionindustriales_0_1850815008.html). 
Hassouneh, I., Serra, T. \& Gil, J.M. 2010. Price transmission in the Spanish bovine sector: the BSE effect. Agricultural Economics, 41(1): 33-42

Hassouneh, I., Serra, T., Goodwin, B \& Gil, J. M. 2010. Non-parametric and parametric modelling of biodiesel, sunflower oil, and crude oil price relationships. Energy Economics, 34(5): 1507-1513.

Hassouneh, I., von Cramon-Taubadel, S., Serra, T. \& Gil, J. M. 2012. Recent developments in the econometric analysis of price transmission. TRANSFOP (Transparency of Food Pricing) Working Paper, (2) (available at eforenergy.org/docpublicaciones/documentos-detrabajo/WPFA06-2013.pdf).

Holst, C., \& von Cramon-Taubdel, S. 2014. Trade, market integration and spatial price transmission on EU pork markets following Eastern enlargement. In 54th Annual Conference, Goettingen, Germany, September 17-19, 2014 (No. 187598). German Association of Agricultural Economists (GEWISOLA).

Ihle, R., Brümmer, B. \& Thompson, S.R. 2012. Structural change in European calf markets: decoupling and the blue tongue disease. European Review of Agricultural Economics, 39(1): $157-180$.

INEC (Instituto nacional de estadística y censo de Panama). 2014. Estimacion de la produccion de leche de vaca en la Republica de Panama: 1993-2013

Johansen, S. 1991. Estimation and hypothesis testing of cointegration vectors in Gaussian vector autoregressive models. Econometrica, 59(6): 1551-1580.

Kinnucan, H. W. \& Zhang, D. 2015. Notes on farm-retail price transmission and marketing margin behaviour. Agricultural Economics, 46: 729-737.

Kim, H., \& Ward, R. W. 2013. Price transmission across the US food distribution system. Food policy, 41: 226-236.

Lloyd, T., McCorriston, S., Morgan, W., \& Rayner, T. 2004. Price transmission in imperfectly competitive vertical markets. Discussion Papers in Economics, (04/09), 1-19.

Martin, W. \& Anderson, K. 2012. Export restrictions and price insulation during commodity price booms. American Journal of Agricultural Economics, 94(2): 422-427.

McCorriston, S. 2013. Transparency of Food Pricing. TRANSFOP. Paper prepared as the OECD Secretariat background paper for the OECD Competition Roundtable in Paris for the special session on "Competition in the Food Chain"

McLaren, A. 2015. Asymmetry in price transmission in agricultural markets. Review of Development Economics, 19(2): 415-433.

Meyer, J. \& von Cramon-Taubadel, S. 2004. Asymmetric price transmission: a survey. Journal of Agricultural Economics, 55(3): 581-611.

MIDA. Ministerio de Desarrollo Agropecuario. 2011. Resolución DAL No. 018-ADM-2011. Gaceta Oficial. Panama, Mayo, 2011.

Miller, D.J. \& Hayenga, M.L. 2001. Price cycles and asymmetric price transmission in the U.S. pork market. American Journal of Agricultural Economics, 83(3): 551-562. 
Panamá América. 2015. Cambios en el sistema de pago preocupa a los prodcutores de leche. Panamá América. 17 March (available at http://www.panamaamerica.com.pa/tema-deldia/cambios-en-el-sistema-de-pago-preocupa-los-productores-de-leche-968210).

Peltzman, S. 2000. Prices rise faster than they fall. Journal of Political Economy, 108(3): 466502.

Perron, P. 1989. The great crash, the oil price shock, and the unit root hypothesis. Econometrica: Journal of the Econometric Society, 1361-1401.

Rapsomanikis, G., Hallam, D. \& Conforti, P. 2003. Market integration and price transmission in selected food and cash crop markets of developing countries: review and applications. In D. Hallam, ed., Commodity Market Review 2003-2004, pp.55-67. Rome, FAO.

Saikkonen, P. \& Lutkepohl, H. 2002. Testing for a unit root in a time-series with a level shift at unknown time. Econometric Theory,18: 313-348

Sanogo, I. \& Amadou, M. 2010. Rice market integration and food security in Nepal: the role of cross-border trade with India. Food Policy, 35: 312-322.

Serra, T. \& Goodwin, B.K. 2002. Price transmission and asymmetric adjustment in the Spanish dairy sector. 2002 Annual meeting, 28-31 July, Long Beach, California, American Agricultural Economics Association.

Sexton, R.J. \& Lavoie, N. 2001. Food processing and distribution: an industrial organization approach. Handbook of agricultural economics, 1: 863-932.

Tapia, S. 2007. Empresas no acogen peticiones de productores. La Prensa, 5 June (available at http://impresa.prensa.com/economia/Empresas-acogen-peticionesproductores_0_2033796781.html).http://impresa.prensa.com/economia/Empresas-acogenpeticiones-productores_0_2033796781.html).

Tapia, S. 2007. Lecheros aceptaron la propuesta de aumento. La Prensa, 7 June (available at http://impresa.prensa.com/economia/Lecheros-aceptaron-propuestaaumento_0_2035296672.html).

Tapia, S. 2007. Lecheros advierten de aumento al consumidor. La Prensa, 7 June (available at http://impresa.prensa.com/economia/Lecheros-advierten-aumento-

consumidor_0_2035296658.html).

Tomek, W. \& Mount, T. 2009. New Econometric Methods for Structural Change Analysis of Agricultural and Food Markets: Discussion. American Journal of Agricultural Economics, 91(5): 1448-1449.

Torres, V. 2007. El paro de los lecheros desabastecerá la industria. La Prensa. 22 May (available at http://impresa.prensa.com/economia/paro-lecheros-desabasteceraindustria_0_2023297843.html).

von Cramon-Taubadel, S. 1998. Estimating asymmetric price transmission with the error correction representation: an application to the German pork market. European Review of Agricultural Economics, 25(1): 1-18.

Wang, D. \& Tomek, W. 2007. Commodity prices and unit root tests. American Journal of Agricultural Economics, 89(4): 873-889. 
Weldegebriel, H.T. 2004. Imperfect price transmission: is market power really to blame? Journal of Agricultural Economics, 55(1): 101-114.

Yin, R. 2013. Case study research: design and methods. London, Sage publications, Inc. 


\section{Chapter 5 Conclusions}

In recent decades, substantial attention has been given to analysis of the level of price transmission in food markets (for reviews see Meyer and von Cramon-Taubadel, 2004; Frey and Manera, 2007; Bakucs et al., 2014). Traditionally, price transmission analysis has been focused on applying econometric methods to assess if prices are co-integrated, the order of cointegration and the adjustment speed. However, less attention has been devoted to the theoretical underpinnings, the understanding of the market structure, and the interpretation of results (Meyer and von Cramon-Taubadel, 2004). Goodwin and Vavra (2009) in an overview of the empirical literature that has addressed vertical and spatial price transmission, highlight that the results of price transmission analysis are not sufficiently informative without a deeper understanding of the market structure relevant to the commodity in question.

Acknowledgment of this issue has stimulated recent studies (Lloyd et al., 2004; Brümmer et al., 2009; Ihle et al., 2012; Götz et al., 2013) to incorporate the use of market structure information in price transmission analyses. This study takes this approach further by exploring how to combine industrial organization (IO) and econometric research methods for price transmission analysis. In the process of testing this approach, the study employs the following: IO to understand the structure of the market and derive preliminary theoretical propositions; time-series econometric methods to assess the spatial and vertical level of price transmission and test the propositions; and triangulation methods to interpret the evidence, linking the empirical results with the propositions. The study uses the Panama's milk market to illustrate this approach.

The first step of the analysis found that Panama's milk market is characterized by an oligopsonistic market structure constituted by a small number of processors and a large number of small producers. The semi-structured interviews with importers reveal that milk powder is 
imported using an auction system open exclusively to those processors holding an import licence. The quota is divided into two main parts: the first part, equivalent to 70 per cent of the quota, is negotiated in November, but physically imported in January during the dry season; the second part, equivalent to 30 per cent of the quota, is negotiated in May and internalized in July during the peak production season. However, if the international price is higher than the domestic price during the first term of the year, processors can request the government to allocate the full quota to the second term.

The focus group discussions with producers identify some factors that might affect the milk market's level of efficiency: the presence of a large number of poorly organized dairy producers combined with a small number of well-articulated industrial processors, leading to the low bargaining power of dairy producers; a perishable product which restricts the geographic movement of raw milk, forcing producers to sell their product through local milk collectors even if prices are higher in other markets; the fear of potential substitution by an alternative supplier if they reduce their delivery quota below a certain level; and a large proportion of fixed and specific inputs that prevent a low-cost reallocation of capital resources in the short run, in addition to cash flow constraints.

The results of the media search reveal that dairy producers and milk industrial processors engaged in a price discussion related to the alleged use of monopolistic practices by industrial processors. The semi-structured interviews with the national antitrust authority (ACODECO) highlight engagement in monopolistic practices by major processors, whereby they agreed a price to be paid at farm gate level. The semi-structured interviews with industrial processors revealed that in Panama most processors manage between two and three months of milk powder stock inventories that allow them to smooth the transmission of the prices both to producers and retailers. Stock inventories are usually lower during the dry season and higher during the rainy season. Thus, processors pay slightly higher prices to producers during the dry season.

Second, we employ an error correction model (ECM), an asymmetric error correction models (AECM), and a vector error correction model (VECM) to assess the price dynamics between global and domestic markets, as well as along the supply chain. The output of the ECM shows the existence of a long-run equilibrium between global and domestic milk prices; however, it 
also indicates that prices changes in the global market are buffered in the domestic market. The results of the AECM reveal that the transmission of milk prices between producers and wholesalers is asymmetric with respect to the speed of adjustment indicating that when producers' prices increase, the speed of adjustment tends to be significantly faster, but when prices decrease, there are no statistically significant changes in the speed of adjustment. Finally, the results of the VECM indicates that a change of 1 per cent in the wholesale prices leads to a change of 4.5 per cent in the producer's price, and following the policy change in 2007 , the price spread between wholesalers and producers decreased from 18 per cent to 13 per cent .

Third, we triangulated the different sources of information. The results indicate that the import quota mechanism obstruct a more complete transmission of price signals from international to domestic markets, suggesting that changes in producers' milk prices in Panama are driven more by domestic rather than international conditions. The presence of a large number of poorly organized dairy producers combined with a high level of market concentration at the industry level, alongside an inelastic price supply function at the producer level has allowed market power to emerge and affect a more complete and symmetric transmission of prices between producers and wholesalers, implying that small dairy producers are not benefiting from price changes as much as they would under a more competitive scenario. The implementation of policy measures to control the monopolistic behaviours of actors has led to improvements in the level of market performance by reducing the price spread margin between producers and wholesalers. Finally, the results point out the potential role of stock inventories in smoothing the transmission of prices from wholesalers to producers as an area for further research.

The econometric and IO methods used here could be extended in several directions; for example, Hassouneh et al. (2012) have pointed out that future research is needed to better capture the nonlinear behaviour of price transmission processes. In this regard, the use of TVECM would be useful to assess the level of price transmission when milk powder stocks are below or above a certain threshold. Given that milk prices regularly increase during the dry season and decrease during the rainy season, following Amikuzuno and von Cramon-Taubadel (2012), model specifications could also be applied to capture the effects of seasonality in the speed of adjustment. One of the main challenges identified during analysis was the difficulty of generalizing from the results obtained from the focus group discussions and the semistructured interviews. Nevertheless, the analysis also revealed that results could be generalized 
to theoretical propositions. In this regard, future research may usefully focus on fewer propositions, narrowing the research question to one determinant factor, for example, imperfect competition, where one might try to better understand "how" and "why" that factor is constraining the transmission of prices. Future research might also place more emphasis on analysis and discussion of major rival explanations in order to strengthen the external validity of results.

This study has shown how to combine the use of IO and econometric research methods for price transmission analysis. With this aim, the research used a three-step approach. First, we employed IO methods to analyse the structure of the milk market; second, we used a VECM to assess the level of price transmission between producers and wholesalers; and finally, we triangulated the different sources of information bringing together the evidence derived from both analyses in order to better understand interrelations among the factors that influence the level of price transmission. A major strength of this approach is its ability to use multiple sources of evidence including documents, media searches, semi-structured interviews, focus group discussions and econometric analysis to better understand the structure of the market and draw inferences concerning price dynamics. However, a weakness is the difficulty of generalizing from the results obtained from the focus group discussions and the semi-structured interviews. The study illustrate the complementarity of these methods to better understand the findings, to corroborate theoretical propositions and to advance theoretical concepts thereby adding to existing theoretical insights on how these factors might be interrelated. The framework presented provides a base to motivate future research studies which will continue to explore how a combination of econometric and IO methods can strengthen the use of price transmission analysis for policy purposes.

Looking backward, I see my research as an evolving process, which moves from the application of econometric methods to assess the level of price transmission to the use of IO methods to better understand the market structure and the underlying causes of incomplete price transmission. Although interest in combining the use of econometric and IO methods remains the same, emphasis of the analysis is shifting. Thus, despite the title of my research highlighting the use of IO methods for price transmission analysis, the results show that there is still a wide range of methods that could be applied to strengthen the IO part of the analysis for example estimating supply and demand elasticities, relating the level of price transmission to these 
parameters. However this is precisely the point where my research is at this moment, and the direction in which is moving.

When I started my research, I struggled to provide some economic and policy interpretations of the econometric model results. Interestingly, during the process I came across qualitative information that highlighted reasons for the incomplete level of price transmission. However, as indicated by an anonymous referee, the qualitative information I presented in my first paper lacked validity since my research methods did not consider a process to collect, analyse and present it. In recognition of the difficulties, of the methodological approaches used to identify and analyse the potential underlying causes of the results, I started searching for an approach that would allow price transmission analysis that makes better use of qualitative information.

In this context, my research started by combining the use of quantitative and qualitative methods in a sequential approach; first applying econometric methods to assess the price dynamics and then qualitative methods to interpret the results. During discussions, it became apparent that it could be more useful to employ a simultaneous approach, whereby the results derived from each step could be used to inform the other. Thus I incorporated as a third step a "methodological triangulation" step, whereby the information derived from the qualitative analysis is use to fine-tune the econometric model, and the information derived from the econometric model is used to sharpen the qualitative research. A major methodological challenge I found during that phase of my research was the generalization of the qualitative findings to draw inferences.

To address this challenge, I substituted qualitative methods with IO methods. In my research approach, the IO analysis departs from the construction of "theoretical propositions" to allow the study to link the empirical results with theory. During discussions it became apparent that the research challenge was not only to identify the potential causes of incomplete price transmission, but also to identify theoretical propositions to be tested using econometric methods. Thus, following recent studies (Yin, 2015), I modified the previous analytical approach by applying econometrics methods to assess the price dynamics and qualitative methods to explain the causes of those dynamics, employing IO methods to demonstrate if the empirical results support or challenge the theory. 
Looking forward, the next phase of my research will be to strengthen and consolidate the triangulation phase of the process. IO methods will be used to develop "theoretical propositions", to gain a better understanding of the market structure, and to provide information to build the econometric model; and econometric methods will assess the price dynamics and test the theoretical propositions. If the results support the theoretical propositions, then the study should explore if the evidence can be generalized to other situations, if not then it should discuss the potential causes and propose rival theoretical explanations.

Future research in this field could focus on strengthening the linkage between price transmission and economic theory. Standard economic theory suggests that the elasticity of price transmission will tend to be close to one in a competitive market, higher than one in an oligopolistic market, and lower than one in an oligopsonistic market. However, empirical evidence suggests that while in some cases price transmission results are well explained by this theory, in others they are not. In this regard, a valuable contribution that coming research could bring to the academic debate, is a well-explained chapter that clearly links price adjustment theory with price transmission analysis. This process will require extensions to the existing economic theory, and the use of industrial organization methods here could provide major contributions. 


\section{References}

Bakucs, Z., Fałkowski, J. \& Fertö, I. 2014. Does market structure influence price transmission in the agro-food sector? A meta-analysis perspective. Journal of Agricultural Economics, 65: $1-25$.

Brümmer, B., von Cramon-Taubadel, S. \& Zorya, S. 2009. The impact of market and policy instability on price transmission between wheat and flour in Ukraine. European Journal of Agricultural Economics, 36(2): 203-230.

Frey, G. \& Manera, M. 2007. Econometric models of asymmetric price transmission. Journal of Economic Surveys, 21(2): 349-415.

Goodwin, B.K. \& Vavra, P. 2009. What can we learn from spatial and vertical price transmission studies?. Empirical examples from U.S. meat markets. Paper prepared for the Courant Research Centre $\backslash$ Poverty, Equity and Growth" Inaugural Conference at the University of Gottingen, Germany.

Götz, L., Glauben, T., \& Brümmer, B. 2013. Wheat export restrictions and domestic market effects in Russia and Ukraine during the food crisis. Food Policy 38: 214-226.

Hassouneh, I., von Cramon-Taubadel, S., Serra, T. \& Gil, J. M. 2012. Recent developments in the econometric analysis of price transmission. TRANSFOP (Transparency of Food Pricing) Working Paper, (2) (available at eforenergy.org/docpublicaciones/documentos-detrabajo/WPFA06-2013.pdf).

Ihle, R., Brümmer, B. \& Thompson, S.R. 2012. Structural change in European calf markets: decoupling and the blue tongue disease. European Review of Agricultural Economics, 39(1): $157-180$.

Lloyd, T., McCorriston, S., Morgan, W., \& Rayner, T. 2004. Price transmission in imperfectly competitive vertical markets. Discussion Papers in Economics, (04/09), 1-19.

Meyer, J. \& von Cramon-Taubadel, S. 2004. Asymmetric price transmission: a survey. Journal of Agricultural Economics, 55(3): 581-611.

von Cramon-Taubadel, S. 1998. Estimating asymmetric price transmission with the error correction representation: an application to the German pork market. European Review of Agricultural Economics, 25(1): 1-18. 